\title{
Cross-presentation of cell- associated antigens by MHC class I in dendritic cell subsets
}

\author{
Enric Gutiérrez-Martínez ${ }^{1}$, Remi Planès ${ }^{1}$, Giorgio Anselmi ${ }^{1}$, Matthew Reynolds ${ }^{1}$, \\ Shinelle Menezes ${ }^{1}$, Aimé Cézaire Adiko ${ }^{2,3}$, Loredana Saveanu ${ }^{2,3}$ and \\ Pierre Guermonprez ${ }^{1 *}$
}

'Laboratory of Phagocyte Immunobiology, Peter Gorer Department of Immunobiology, CMCBI, King's College London, London, UK, ${ }^{2}$ Laboratory of Phagocyte Immunobiology, Peter Gorer Department of Immunobiology, Centre for Molecular \& Cellular Biology of Inflammation (CMCBI), King's College London, Paris, France, ${ }^{3}$ Sorbonne Paris Cité, Université Paris Diderot, Paris, France

OPEN ACCESS

Edited by:

Stephanie Hugues, Université de Genève, Switzerland

Reviewed by: Elodie Segura, Institut Curie, France Bénédicte Manoury, INSERM U1013 Hôpital Necker, France

*Correspondence: Pierre Guermonprez, CMCBI, Guy's Hospital, Great Maze Pond, New Hunt's House, First Floor 1.32H, London SE1 1UL, UK pierre.guermonprez@kcl.ac.uk

Specialty section: This article was submitted to Antigen

Presenting Cell Biology, a section of the journal Frontiers in Immunology

Received: 02 April 2015 Accepted: 05 July 2015 Published: 17 July 2015

Citation:

Gutiérrez-Martínez E, Planès $R$, Anselmi G, Reynolds M, Menezes S,

Adiko AC, Saveanu $L$ and

Guermonprez P (2015) Cross-

presentation of cell-associated antigens by $\mathrm{MHC}$ class I in dendritic cell subsets.

Front. Immunol. 6:363. doi: 10.3389/fimmu.2015.00363
Dendritic cells (DCs) have the unique ability to pick up dead cells carrying antigens in tissue and migrate to the lymph nodes where they can cross-present cell-associated antigens by $\mathrm{MHC}$ class I to $\mathrm{CD}^{+} \mathrm{T}$ cells. There is strong in vivo evidence that the mouse $\mathrm{XCR} 1{ }^{+}$DCs subset acts as a key player in this process. The intracellular processes underlying cross-presentation remain controversial and several pathways have been proposed. Indeed, a wide number of studies have addressed the cellular process of cross-presentation in vitro using a variety of sources of antigen and antigen-presenting cells. Here, we review the in vivo and in vitro evidence supporting the current mechanistic models and disscuss their physiological relevance to the cross-presentation of cell-associated antigens by DCs subsets.

Keywords: cross-presentation, cross-priming, dendritic cells, antigen processing, MHC class I, phagocytosis

Cross-presentation is the process by which exogenous antigens captured by phagocytic antigenpresenting cells are processed and presented onto MHC-I molecules $(1,2)$. Early evidence supports the notion that cell-associated antigens are a physiological substrate for cross-presentation. Indeed, cross-presentation was discovered in the context of $\mathrm{CD}^{+} \mathrm{T}$ cell responses to grafts: Bevan et al. demonstrated that engraftment of $\mathrm{H}-2^{\mathrm{b}}$ cells primes $\mathrm{H}-2^{\mathrm{dxb}} \mathrm{F} 1$ mice for a cytotoxic $\mathrm{CD} 8^{+} \mathrm{T}$ cell response against minor histocompatibility antigens restricted by $\mathrm{H}-2^{\mathrm{d}}(1-3)$. Therefore, minor histocompatibility cellular antigens from the grafted cells are "cross-presented" by recipient antigen-presenting cells to $\mathrm{CD} 8^{+} \mathrm{T}$ cells, a process termed cross-priming because it is associated with productive $\mathrm{CD} 8^{+}$ $\mathrm{T}$ cell activation ( $\mathrm{cf}$ below). Later on, these findings were translated to tumor antigens as it was shown that MHC restriction elements were not required on the tumors to cross-prime tumor-specific $\mathrm{CD}^{+} \mathrm{T}$ cells $(4,5)$. Importantly, cross-priming antigen-presenting cells were found to originate in the bone marrow (4-6). The immunological outcome of cross-presentation depends on the DC activation state. Cross-priming is achieved by cross-presenting DCs that have received proper conditioning by pattern recognition receptor ligation or helper $\mathrm{CD} 4^{+} \mathrm{T}$ cells (7). By contrast, crosspresenting "steady-state" DCs mediate the functional inactivation of $\mathrm{CD} 8^{+} \mathrm{T}$ cells, a process termed cross-tolerization (8-10). Self-antigens like the one expressed in pancreatic $\beta$-cells, for example, were shown to enter the cross-presentation pathway constitutively for a tolerogenic outcome $(8,9)$. Therefore, cross-presentation might participate in the maintenance of peripheral tolerance to tissuespecific antigens (11). Also, cross-presentation of thymic epithelium self-antigens by bone marrowderived cells can participate in the negative selection of auto-reactive $\mathrm{CD} 8^{+} \mathrm{T}$ cells (12). Importantly, 
cross-presentation might be mobilized to cross-prime $\mathrm{CD}^{+} \mathrm{T}$ cell responses specific to cell-associated viral antigens $(4,6,13,14)$. Heath and Carbone have proposed that the cross-presentation is an evolutionary response to evasion mechanisms associated with the direct infection of DCs by viruses (e.g., the inhibition of direct presentation or migratory behavior) (7). This view is supported by recent evidence that DCs can perform cross-presentation during infection without being infected (15). In all these situations (grafts, tumors, viral antigens), antigens are associated with cells reach the endocytic pathway of DCs where they gain access to the cross-presentation pathway for MHC-I presentation. In vitro, pioneer work from Bellone et al. (16) and Albert et al. (13) showed that the engulfment of dead cells by murine macrophages (16) or human monocyte-derived DCs (moDCs) (13) support the crosspresentation of cell-associated antigens by MHC-I. Quantitative studies demonstrated that association of protein antigen to dying cells considerably lowered the amount of antigen required for efficient cross-presentation in vivo (17). In vivo, cross-presentation is biased toward highly expressed cellular antigens and favored by cellular destruction (18), including cellular destruction dependent on cytotoxic CD8 ${ }^{+}$lymphocytes (18) or NK cells (19). Although other mechanisms might exist [nibbling, cytotoxicity by DCs $(20-22)]$ these findings support the view that the phagocytosis of dead cells by DCs is an efficient mechanism underpinning the acquisition of antigens by cross-presenting APCs. Proteins, as opposed to proteasomal products (i.e., peptides), constitute the source of cell-associated antigens entering the cross-presentation pathway (23). Stable membrane proteins (24), in particular, are better cross-presented than soluble, short-lived cytosolic proteins or epitopes within signal peptides $(25,26)$. In summary, there is extensive in vivo evidence acquired in mouse models, and in vitro with human cells, supporting the relevance of cross-presentation by MHC-I for $\mathrm{CD}^{+} \mathrm{T}$ cell responses to cell-associated antigens. Here, we will review the current evidence identifying dendritic cells (DCs) as major players in the cross-presentation of cellassociated antigens and the mechanistic models that have been proposed to explain this phenomenon.

\section{Mouse and Human DC Subsets}

Dendritic cells are classified as conventional DCs (cDCs) or plasmacytoid DCs (pDCs). cDCs represent a heterogeneous set of cells found in lymphoid and non-lymphoid tissues that: (i) pick-up and process antigens by MHC class I and class II molecules, (ii) activate naive $\mathrm{CD}^{+}$and $\mathrm{CD} 8^{+}$T cells (27-31), (iii) express a specific gene signature including the lineage-specific Zbtb46 transcription factor $(30,32)$, (iv) rely on Flt3 receptor tyrosine kinase and its ligand for their development $(33,34)$, and (v) migrate toward $\mathrm{T}$ cell zones of lymphoid organs by using the chemokine receptor CCR7 $(35,36)$. In both mice and humans, cDCs can be classified into two subtypes, the XCR1 $1^{+} \mathrm{DCs}$ and the XCR1- DCs (" $\mathrm{CDC1}$ " and "CDC2," respectively, according to a recent nomenclature proposition)(37-39). In mice, the $\alpha \mathrm{E}$ integrin CD103 is expressed on XCR $1^{+}$DCs with the notable exception of the gut where it is also expressed on a subset of XCR1- DCs ontogenically distinct from cDC1 (40). Also, lymphoid organ-resident XCR1 ${ }^{+}$cDC1s express high levels of CD $8 \alpha$ (40). cDC1s express some levels of the langerin protein also found in epidermal Langerhans cells (LCs) (41-43). Based on these findings, Langerin-DTR mice have been largely used as a model of DT-inducible conditional ablation of cDC1s (44-46). Overall, mouse cDC1s from various organs lymphoid or non-lymphoid share some common transcriptional programs and genetic requirements (e.g., Id2, IRF8, Batf3) $(36,40)$. In humans, $\mathrm{XCR} 1^{+} \mathrm{cDC} 1 \mathrm{~s}$ express BDCA3, while XCR1 ${ }^{-} \mathrm{cDC} 2 \mathrm{~s}$ express BDCA1/CD1c $(37,39,47-49)$. Both murine and human $\mathrm{cDC} 1 \mathrm{~s}$ share a common transcriptional program characterized by high levels of TLR3, Clec9a/DNGR1 C-type lectin, and the IRF8 transcription factor $(37,39,47-49)$. In vivo evidence obtained in Batf $3^{-1-}$ mice (50) and in vitro silencing studies in human CD $34^{+}$ progenitors identified Batf3 as a transcription factor relevant for cDC1 development in both species (51). Conversely, mouse and human cDC2s express high levels of IRF4 and TLR7 [mouse (52)] or TLR8 [humans $(39,53-56)]$. Whereas IRF4 is required for the development of CDC2 in mice (57), it is not known if this holds true for human cDC2s. IRF4 is a master regulator of antigen presentation by major histocompatibility complex class II (MHC-II) through the induction of CIITA, the master transcription factor controlling the expression of MHC-II genes and accessory proteins (Ii, H-2DM) (58). Both $\mathrm{cDC1}$ and $\mathrm{cDC} 2$ subsets are hematopoietic cells that develop from DC-committed, common DC precursors (CDPs) identified both in mice $(59,60)$ and more recently in humans (61). CDPs arise from common progenitors for DCs and monocytes $(61,62)$ and give rise to circulating precursors called pre-cDCS $(63,64)$. Finally, fate mapping studies $(65,66)$ and bar-coding of multipotent progenitors (67) identify cDCs as a bona fide hematopoietic lineage distinct from other mononuclear phagocytes and the lymphoid lineage.

Discrepancies between developmental abnormalities observed in cDC subsets in IRF8 mutant mice $(57,68,69)$ and IRF8 mutant patients cast some doubt upon the actual level of orthology between human and mouse subsets. Indeed, $\operatorname{Irf} f 8^{-1-}$ mice are fully deficient in $\mathrm{CDC1}$ (and pDCs and monocytes) but not $\mathrm{cDC} 2$. IRF8 $^{\mathrm{R} 294 \mathrm{C}}$ hypomorphic mutant mice (69) are also deficient in cDC1 (but not pDCs). By contrast, human genetic studies showed that patients with the IRF8 ${ }^{\mathrm{K} 108 \mathrm{E}}$ mutation are deficient in both $\mathrm{CDC} 1$ and $\mathrm{CDC} 2$ (and monocytes), whereas a patient with the IRF8 ${ }^{\mathrm{T} 80 \mathrm{E}}$ mutation selectively lacked circulating $\mathrm{BDCA}^{+} \mathrm{CDC} 2$ (70). Therefore, the conservation of developmental requirements between mouse $\mathrm{CDC} 1$ and human $\mathrm{CDC} 1$, if any, remains to be fully understood.

Plasmacytoid DCs represent a heterogeneous group of cells expressing specific markers in mice (PDCA-1, SiglecH) and humans (BDCA2/CD303, CD123). Mouse and human pDCs exhibit a high level of conservation in their gene expression pattern (71). Both rely on the Tcf4/E2-2 bHLH transcription factor (72) [and its Spi-B target gene $(73,74)$ ] and can be generated from CDPs and other Flt3 ${ }^{+}$progenitors $(61,75-77)$.

Finally, moDCs represent a heterogeneous set of cells that are different from cDCs because: (i) they originate from monocytes and not pre-cDCs, (ii) they are absent at the steady state, (iii) in vivo, they rely on Ccr2-dependent egress of the bone marrow $(78,79)$. In vivo, moDCs arise in various inflammatory conditions triggered by exposure to foreign objects such as recall antigens (mBSA) (80), LPS (81), or during infections such as Listeria 
monocytogenes $(82,83)$. Listeria-induced $\mathrm{iNOS}^{+}$moDCs are independent of GM-CSF (83) while mBSA-dependent moDCs rely on GM-CSF (80). In vitro generated GM-CSF-derived DCs (84) are a popular source of DCs for cellular studies even if they are developmentally distinct from cDCs (85).

\section{In vivo Evidence for the Role of Murine cDC1 in Cross-Presentation}

If cross-presentation can be obtained using multiple antigenpresenting cells in vitro, including moDCs or macrophages for example, the available in vivo evidence suggests that cross-presentation is mostly performed by the mouse $\mathrm{CD} 8^{+} / \mathrm{CD} 103^{+}$subset of $\mathrm{cDCs}(\mathrm{cDC} 1 \mathrm{~s})$. Evidence supporting this paradigm was obtained by analyzing ex vivo MHC-I peptide complexes on spleen DCs sorted from mice that had previously received an intravenous injection of OVA antigen-loaded cells (86). CD $8 \alpha^{+} \mathrm{CD}_{11} \mathrm{~b}^{-} \mathrm{cDC} 1$ but not the $\mathrm{CD} 8 \alpha^{-} \mathrm{CD} 11 \mathrm{~b}^{+} \mathrm{cDC} 2$ were found to perform crosspresentation. $\mathrm{cDC} 1 \mathrm{~s}$ were also involved in the constitutive crosspresentation of a pancreatic model antigen (RIP-OVA) $(8,9,87)$. Also, lung $\mathrm{CDC} 1 \mathrm{~s}$ pick up intranasally delivered soluble antigens or cell-associated antigens, transport them to mediastinal lymph nodes, and perform cross-presentation $(88,89)$.

Which DC subsets perform cross-presentation during viral infections? Allan et al. have shown that upon HSV skin infection, skin migratory DCs, but not radio-resistant LCs, were responsible for the early transport of antigens to the lymph node, where antigen is transferred to lymphoid resident $\mathrm{CD}^{+} \mathrm{CDC} 1 \mathrm{~s}$, mediating $\mathrm{CD}^{+} \mathrm{T}$ cell priming $(90,91)$. Similar findings advocating a major role for lymphoid organ-resident cDC1s cross-presenting cellassociated antigens have been reported in multiple infection systems (92). Later on, this idea was challenged by Bedoui et al. who addressed the efficiency of ex vivo presentation by the different DC subsets after 5 days of infection with HSV-1 (93). The isolation of DCs from axillary lymph nodes draining a site of secondary infection (associated with viral recrudescence) demonstrated that the $\mathrm{CD}_{103^{+}}$migratory $\mathrm{cDC} 1 \mathrm{~s}$ had a predominant role in the presentation of viral antigens to specific $\mathrm{CD}^{+} \mathrm{T}$ cells ex vivo (93). However, ex vivo $\mathrm{T}$ cell activation in this system does not discriminate between cross-presentation and direct presentation. Bedoui et al. obtained formal evidence of the role of migratory CDC1 in cross-presentation using a membrane-associated form of ovalbumin (OVA) expressed in epidermal keratinocytes (93). Finally, selective depletion of migrating langerin ${ }^{+} \mathrm{cDC} 1 \mathrm{~s}$ (but not LCs) was shown to be required for the constitutive cross-presentation of keratinocyte antigens formally demonstrating the key role of migratory cDC1s in cross-presentation of cell-associated antigens from the periphery (46).

Upon lung Influenza virus infection, there is an increase in the population of langerin ${ }^{+} \mathrm{CD} 103^{+} \mathrm{CD} 11 \mathrm{~b}^{-} \mathrm{CD} 11 \mathrm{c}^{+} \mathrm{cDC} 1 \mathrm{~s}$ in the mediastinal lymph node (94). The depletion of this population of cells in Langerin-DTR mice leads to a decrease in the clearance of Influenza virus together with a significant decrease in $\mathrm{CD}^{+}$cytotoxic responses (94). Importantly, a subsequent study showed that among all the DC subsets in mice infected with a recombinant influenza virus, only the lung $\mathrm{CD}_{103}{ }^{+} \mathrm{cDC} 1$ s carried antigens from a recombinant Influenza virus expressing a green fluorescent protein (GFP) fused to NS1, a non-structural protein of the virus, to the draining lymph node (15). Importantly, CD103+ $\mathrm{cDC}$ s carrying $\mathrm{GFP}^{+}$material derived from infected cells were not infected. Therefore, this study elegantly demonstrated that cross-priming DCs mediate CCR7-dependent delivery of cellassociated viral antigen to draining lymph nodes without being infected (15). Also, depletion of cDC1s in Batf3 $3^{-1-}$ mice abrogates $\mathrm{CD}^{+} \mathrm{T}$ cell responses to West Nile virus, but the contribution of cross-presentation in this process is not formally established (50). Altogether, the migratory $\mathrm{CD} 103^{+} \mathrm{cDC} 1 \mathrm{~s}$ have emerged as a pivotal DC population in the control of $\mathrm{CD}^{+} \mathrm{T}$ cell responses, especially in the context of viral infections.

$\mathrm{CD} 103^{+}$DCs might also have a role in other types of infections. Splenic $\mathrm{CD}^{+} \mathrm{cDC} 1 \mathrm{~s}$ isolated from the spleens of mice infected with Plasmodium berghei ANKA were much more efficient in cross-presenting malaria antigens than CDC2s (95). As a consequence, depletion of $\mathrm{cDC1}$ s in Langerin-DTR mice (96) or Clec9a-DTR (97) mice abrogates immuno-pathological $\mathrm{CD}^{+} \mathrm{T}$ cell responses associated with $P$. berghei ANKA infection. In the case of malaria infection, cross-presentation is absolutely required for $\mathrm{CD}^{+} \mathrm{T}$ cell responses, since parasites invade only red blood cells devoid of MHC class I(98).

\section{Are Other DCs Types Involved in Cross-Presentation In vivo?}

Monocyte-derived DCs generated in inflammatory conditions in vivo are capable of cross-presenting, to some extent, soluble OVA or OVA expressed by E.coli $(81,99)$. However, it is unclear if this mode of cross-presentation is relevant for the induction of $\mathrm{CD}^{+} \mathrm{T}$ cells in vivo, in particular against cell-associated antigens. Immunization based on skin inflammation was shown to involve CCR6-dependent inflammatory cells that crosspresent to $\mathrm{CD}^{+} \mathrm{T}$ cells (100). Also, moDCs might support the expansion of antigen-experienced $\mathrm{CD}^{+} \mathrm{T}$ cells in the periphery (101). If these studies $(100,101)$ implicate moDCs in antigen presentation to $\mathrm{CD}^{+} \mathrm{T}$ cells, it remains unknown if moDCs can perform the cross-presentation of cell-associated antigens in vivo. Interestingly, it has been shown that circulating CD14 monocytes of chronic HBV patients contain big amounts of viral antigen that are mobilized to elicit $\mathrm{T}$ cell proliferation when they are differentiated into moDCs (102).

In spite of the lack of cross-presenting activity in steadystate conditions, one study showed that upon stimulation with TLR7 agonists in vivo or in vitro, the capacity of splenic pDCs to cross-present antigens was increased suggesting that they might contribute to cross-presentation in vivo (103). However, depletion of pDCs by the injection of 120G8 antibodies does not affect $\mathrm{CD}^{+}$CTL responses to Influenza (94). Likewise, the administration of OVA coupled to a PDCA-1 antibody which would direct the antigens to the pDCs does not elicit $\mathrm{CD}^{+}$ responses in the absence of cDCs (104). Taken together, there is little evidence for a role of $\mathrm{pDCs}$ in cross-presentation in vivo despite the recent evidence of their contribution to some CD8 ${ }^{+}$ anti-viral responses, through the orchestration of innate immune responses $(105,106)$. 


\section{Are Human cDC1 Specialized in Cross-Presentation?}

There is currently some controversy on whether human $\mathrm{cDC} 1 \mathrm{~s}$ are endowed with a better cross-presenting ability than cDC2s. Many reports have analyzed the cross-presentation of antigens associated with necrotic cells to antigen-specific $\mathrm{CD}^{+} \mathrm{T}$ cell clones in vitro. Using HIV-infected necrotic cells, Crozat et al. reported that $\mathrm{CDC} 1 \mathrm{~s}$ are more efficient at stimulating a $\mathrm{CD} 8^{+} \mathrm{T}$ cell line specific for the HIV protein pol (37). Jongbloed et al. analyzed cross-presentation of HCMV-infected necrotic fibroblast to pp65specific $\mathrm{CD}^{+} \mathrm{T}$ cells and reported similar findings using DCs purified from blood (48). Finally, Bachem et al. also concluded the superiority of blood cDC1s in cross-presenting cell-associated antigens from freeze-thawed transfectants expressing the pp65 HCMV protein (47). By analyzing the tonsil-derived cDC1s, cDC2s, and pDCs, Segura et al. concluded that both cDC1s and cDC2s have a similar ability to cross-present cell-associated antigens that is not shared by pDCs $(107,108)$. In contrast, Tel et al. showed that pDCs can cross-present receptor-targeted Ags to cytotoxic T lymphocytes so efficiently as CDC1 (109).

Finally, Haniffa et al. have identified a skin CD141 ${ }^{+} \mathrm{cDC} 1$ subset capable of cross-presenting a hepatitis B surface antigen (HBsAg) to specific $\mathrm{CD}^{+} \mathrm{T}$ cell clones upon stimulation with TLR3 agonists and exposure to a cytokine maturation cocktail (110).

Some experiments, however, support the idea that $\mathrm{cDC} 1 \mathrm{~s}$ might be endowed with a better ability to cross-present exogenous antigens independently of dead cell engulfment. Indeed, two studies have reported that $\mathrm{CDC} 1 \mathrm{~s}$ have a better ability to cross-present soluble proteins to antigen-specific $\mathrm{CD}^{+} \mathrm{T}$ cell clones $(47,48)$. This result is in stark contrast to the data of Segura et al. who did not identify a detectable cross-presentation activity for a long peptide in circulating, non-activated $\mathrm{CDC} 1 \mathrm{~s}$ and $\mathrm{cDC} 2 \mathrm{~s}$ (107). Both cDC1s and cDC2s from the tonsil, however, were found to be able to cross-present soluble antigens (long peptides and protein antigens) efficiently, together with pDCs (108). Also, pDCs have been reported to cross-present vaccinal lipopeptides and HIV-1 antigens from apoptotic cells to specific $\mathrm{CD}^{+} \mathrm{T}$ lymphocytes as efficiently as cDC2 (111).

Dendritic cells derived from $\mathrm{CD} 34^{+}$hematopoietic progenitors are increasingly used as a convenient model for the study of cross-presentation by DCs. Pioneering work by Poulin et al. has characterized the $\mathrm{CDC} 1$ progeny of $\mathrm{CD} 34^{+}$progenitors differentiated in a Flt3L/SCF/GMCSF/IL4 cytokine cocktail (49). Poulin et al. have shown that $\mathrm{CDC} 1$-like TLR3 ${ }^{+} \mathrm{Clec} 9 \mathrm{a}^{+}$cells were capable of cross-presenting Melan-A long peptide upon polyI:C activation (49). Using a similar culture system, by systematic comparison of $\mathrm{cDC} 1 \mathrm{~s}$ and $\mathrm{cDC} 2 \mathrm{~s}$, Balan et al. have found that $\mathrm{XCR} 1^{+}{ }^{-T L R} 3^{+} \mathrm{Clec} 9 \mathrm{a}^{+} \mathrm{cDC} 1 \mathrm{~s}$ have a better ability to cross-present cell-associated HCMV pp65 associated with K562 cells than BDCA1/CD1 $c^{+}$cDC2s (112). These data contrast with the study of Proietto et al. showed that both $\mathrm{CDC} 1$ and $\mathrm{CDC} 2$ obtained in Flt3L/TPO cocktail do not display differences in the crosspresentation capability of an Influenza virus protein to a specific $\mathrm{CD}^{+} \mathrm{T}$ cell (113). Finally, Segura and Kletchevksy have firmly established the cross-presentation abilities of $\mathrm{CD} \mathrm{a}^{+} \mathrm{DC}$ derived from $\mathrm{CD} 34^{+}$cord blood progenitors cultivated in GMCSF/Flt3L/
TNF- $\alpha(108,114)$. The developmental and phenotypic relationship of these cells that share a lot of features with epidermal LCs (114) raise some interesting questions on the regulation of cross-presentation in vivo in the human system. Supporting this idea, another group showed that human LCs were, at steady state, more efficient than dermal DCs in cross-presenting long peptides to $\mathrm{CD}^{+} \mathrm{T}$ cells, (115).

\section{Is the Ability to Engulf Dead Cells Associated with a Specific DC Subset?}

Den Haan et al. first identified the mouse DC1 subset as the main phagocytic subset involved in the phagocytic uptake of dead cells in situ (86). Iyoda et al. later extended these findings in the context of NK-mediated killing of allogeneic targets (19). More recently, Desch et al. have identified that mouse lung $\mathrm{CDC} 1 \mathrm{~s}$ have a specific ability to pick up intranasally delivered dead cells (89).

In summary, there is a general agreement on the fact that murine cDC1s have a higher ability to pick up dead cells as compared to $\mathrm{CDC} 2 \mathrm{~s}$. In humans, however, the situation is not that simple. Jongbloed et al. found that the superiority of DC1s (as compared to $\mathrm{CDC} 2 \mathrm{~s}$ ) has not been attributed to a specific ability to pick up material from dead cells (48). By contrast, Segura et al. found that both $\mathrm{cDC} 1 \mathrm{~s}$ and $\mathrm{cDC} 2 \mathrm{~s}$ (but not $\mathrm{pDCs}$ ) were found capable of engulfing dead cell material from fluorescently necrotic cells $(107,108)$. Despite their ability to perform cross-presentation of long peptides and proteins with the same efficiency as $\mathrm{CDC} 1 \mathrm{~s}$ or $\mathrm{cDC} 2 \mathrm{~s}, \mathrm{pDCs}$ are poorly able to engulf material from dead cells and to cross-present cell-associated antigens (107, 108). In summary, unlike in the mouse system, both human $\mathrm{CDC} 1$ and cDC2 seem to be able to pick up necrotic dead cell material with no obvious differences in efficiency.

\section{What are the Receptors Implicated in the Uptake of Dead Cells by cDCs?}

The mechanisms of dead cell engulfment by macrophages are complex and involve multiple receptors that have cooperative or redundant roles (116). Phosphatidylserine exposure associated with cell death engages directly macrophage receptors (e.g., TIM4, CD36) and also leads to the deposition of multiple opsonins (e.g., MFGE8, Gas6, protein S) engaging various macrophage receptors (e.g., alphaV integrins or MerTK/Axl tyrosine kinases). Dead cell uptake in macrophages requires a coordinated process of direct recognition of "eat-me" signals and the subsequent activation of intracellular signaling pathways. For example, TIM4 receptors mediate the uptake of dead cells to the macrophage plasma membrane by direct recognition of phosphatidylserine (117), whereas tyrosine kinases like MerTK triggers a signaling cascade that leads to an actin-remodeling process promoting engulfment (118). Initial work by Albert et al. showed that the alphaVbeta5 ( $\alpha \mathrm{V} \beta 5)$ integrin and CD36 scavenger receptor play an important role in dead cell uptake by human moDCs (119). However, murine DC1 spleen cells from $C d 36^{-/-}$and $\beta 3 \beta 5^{-/-}$mice are not deficient in the uptake of dead cells and cross-presentation $(120,121)$. By contrast, neutralizing antibodies to $\alpha \mathrm{V}$ integrins and CD36 inhibits efferocytosis by human splenic CD141 ${ }^{+}$cDC1s (122). Therefore, 
the involvement of CD36 and aV integrins in dead cell uptake by DCs remains controversial, as it is not clear if DCs and macrophages share similar mechanisms to perform efferocytosis. In this sense, evidence for specific cell-type efferocytic mechanisms are reinforced by a study showing that the inhibition of phosphatidylserine recognition in vivo impairs macrophage dead cell uptake, but promotes efferocytosis by spleen CD8 $\alpha^{+}$DCs (123).

Mouse cDC1s express DEC205 (124) and DNGR1/Clec9a (125) lectins and both have the ability to bind to dead cells. Analysis of $\mathrm{DEC} 205^{-/-}$(19) failed to reveal any default in the internalization of dead cells by cDC1s. Clec9a/DNGR1, in particular, has been shown to bind filamentous actin (126-128) and is also selectively expressed by mouse and human cDC1s $(49,51$, $129,130)$. Surprisingly, in spite of its ability to bind to necrotic cells by engaging filamentous actin (126-128), Clec9a/DNGR1 is not controlling the uptake of dead cells by the cDC1s DCs $(125,129,130)$.

More recently, TIM3 has been involved in the phagocytosis of apoptotic cells by the mouse DCs (131). Anti-TIM3 antibodies inhibit efferocytosis by mouse cDC1s in vitro and in vivo, and partially decrease cross-presentation as well $(122,131)$. Although the role of TIM3 in cross-presentation by human cDCs has not been assessed, a recent paper has shown that TIM3 is highly expressed in tumor-associated cDCs in humans (132). Another scavenger receptor, SCARF-1, has also been involved in efferocytosis in mouse CDC1 (133) although the administration of neutralizing anti-SCARF-1 antibodies does not have any effect on the efferocytosis by human spleen CDC1 (122). Whether SCARF-1 plays a role in cross-presentation has not been established. Finally, the Axl tyrosine kinase has also been involved in efferocytosis by DCs (122). Axl would mediate the recognition of opsonized dead cells while RANBP9 mediates its interaction with the LRP1 phagocytic receptor (122). Inactivation of either member of this complex leads to pronounced reduction in dead cell uptake by mouse $\mathrm{cDC1}$ with the subsequent decrease in cross-presentation of cell-associated antigens. Importantly, antibody blockade indicates that Axl and Lrp1 are also needed for the uptake of dead cells by human splenic cDC1 (122).

In summary, mouse and human $\mathrm{CDC}$ subsets might recruit overlapping as well as distinct set of receptors to mediate the engulfment of dead cells. Whether the nature of cell death might influence these choices and the cellular consequences for crosspresentation of cell-associated antigens remains to be analyzed.

\section{Does Antigen Targeting to Endocytic Receptors Trigger Cross-Presentation in all Subsets?}

If murine cDC1s have a clear advantage in dead cell uptake as compared to $\mathrm{CDC} 2 \mathrm{~s}$, it is conceivable that additional intracellular processes might also contribute to efficient cross-presentation of cell-associated antigens. In support of this notion, Schnorrer et al. have shown that phagocytic $\mathrm{cDC} 1$ cross-presents OVA more efficiently than $\mathrm{CDC} 2$, even at normalized amounts of phagocytozed antigen (134). Is it possible to overcome these subset-specific differences in cross-presentation efficiency by increasing the efficiency of antigen loading by targeting endocytic receptors? For example, experiments from the Cresswell laboratory have demonstrated that 293T cells rendered phagocytic by enforced expression of FcgRIIA are capable of cross-presenting antibody-targeted antigens (135). Therefore, it is tempting to conclude that every cell is able to perform cross-presentation provided that exogenous antigens are delivered efficiently inside the endocytic pathway. Complex particles like bacteria (136) or yeast (137), engaging multiple receptors and triggering cell activation, overcome the superiority of mouse $\mathrm{CDC} 1$ to perform cross-presentation, at least in vitro (138). However, by carefully measuring the rates of antigen uptake, Kamphorst et al. were able to demonstrate the superiority of cross presentation efficiency by cDCs ( $\mathrm{cDC} 1$ or $\mathrm{CDC} 2)$ over GMCSF-induced moDCs regardless of the route of antigen capture (receptor-mediated endocytosis, macro-pinocytosis or phagocytosis) (139). Therefore, cDCs appear to be endowed with a kind of capability to perform cross-presentation, irrespectively of $\mathrm{cDC} 1 / \mathrm{cDC} 2$ subset, more efficiently than other phagocytic cell types even if antigen is delivered through receptor-mediated endocytosis (139).

Elegant experiments from the Nussenzweig laboratory have established that targeting of exogenous antigen to mouse DEC205 via antigen-antibody conjugates leads to efficient antigen cross-presentation in $\mathrm{CDC1}$ cells that selectively express DEC205 $(10,140)$. When targeted to CDC2s, the same antigen is not cross-presented efficiently (140). Transgenic expression of human DEC205 in both $\mathrm{cDC} 1$ and $\mathrm{cDC} 2$ cells using the CD11c promoter and antibody-mediated targeting was instrumental in showing that (i) efficient capture of OVA by huDEC205 leads to efficient cross-presentation by both $\mathrm{CDC} 1$ and $\mathrm{CDC} 2$ and (ii) in the same cells (cDC2), huDEC205 leads to better crosspresentation than DCIR2 targeting (139). Unlike mouse DEC205, human DEC205 is expressed in both human cDC1s and cDC2s. Efficient cross-presentation is achieved in both $\mathrm{cDC} 1 \mathrm{~s}$ and $\mathrm{CDC} 2 \mathrm{~s}$ when antigen is targeted to CD40 or CD11c but not DEC205 despite the ability of DEC205 to trigger efficient internalization of antibody-antigen conjugates in both subsets $(141,142)$. In conclusion, the level of subset specificity achieved by receptor targeting in cross-presentation is fully dependent on the endocytic receptor used $(139,141,142)$. Overall, cDC2 are largely able to perform efficient cross-presentation upon targeting of antigen to some specific receptors $(139,141,142)$. These findings are important for the design of vaccines (143), but one may wonder if receptor-dependent cross-presentation by $\mathrm{cDC} 2 \mathrm{~s}$ is physiologically relevant. In physiological settings, antibody-mediated uptake by FcyR might significantly boost the cross-presentation of antigens by cDC2s. This was shown in vitro, for example, with the cDC2-like D1 cell line or moDCs (144) and in vivo after the injection of immune complexes (145). This mode of uptake might serve the cross-presentation of cell-associated antigens when antibodies raised against cell surface antigens mediate cellular engulfment (146). This situation might be important in the context of immune responses to viral infections when antibodies might bind viral glycoproteins at the surface of infected cells and promote the cross-presentation of cell-associated viral antigens. Also, antibodies against model membrane antigens expressed in pancreatic $\beta$ cells activate its cross-presentation in vivo (147). 


\section{Cytosolic Versus Vacuolar Cross-Presentation}

What are the intracellular mechanisms of antigen processing and presentation underpinning cross-presentation? Currently, there are two main models explaining how antigens can be processed to load MHC-I receptors for cross-presentation. These models are referred to as "cytosolic" and "vacuolar" pathways. In the cytosolic model, antigens are released from the lumen of phagocytic compartments to the cytoplasm where they are further processed into short peptides by the proteasome (148). The transporters associated with antigen processing (TAP1/ TAP2) translocate proteasomal peptide products to the lumen of the MHC class I loading compartment where they gain access to the MHC-I loading machinery including tapasin, ERp57, and calreticulin (148). The first evidence supporting the so-called cytosolic model came from studies using antigen associated with beads and macrophages as the source of antigen-presenting cells (149). Importantly, this study demonstrates the existence of a phagosome-to-cytosol transport pathway. Indeed, coupling of the gelsolin protein toxin to beads was sufficient to mediate its cytosolic delivery probed functionally by translational inhibition (149). Cross-presentation of phagocytosed antigen was inhibited by proteasome inhibitors, genetic inactivation of the TAP1/TAP2 transporters and Golgi disruption by brefeldin A, a Golgi-disrupting agent (149). These experiments constitute the foundation of the cytosolic model of cross-presentation in which phagocytosed antigens are processed within the cytosol by the proteasome in a similar way to endogenous antigens. TAP requirement for cross-presentation has also been identified for cell-associated antigens in vivo $(6,150)$. Favereau et al. have shown that the cross-presentation of cell-associated antigens by human moDCs uses the cytosolic pathway (151). However, the criterion of TAP requirement has to be considered with some caution since genetic inactivation of TAP1 or TAP2 destabillizes MHC-I and impairs its transport at the cell surface (152). As a consequence, low-temperature incubations, which restore the levels of MHC-I at the plasma membrane in $\mathrm{TAP}^{-/-}$cells, can rescue the cross-presentation of phagocytosed antigens (153, 154). In addition to TAP requirement, experimental evidence of the cytosolic pathway relies on pharmacological proteasome inhibition.

In the vacuolar pathway, extracellular antigens are internalized and degraded in the endosomal compartments by lysosomal enzymes, and the resulting peptides are loaded onto MHC-I molecules within the endosomal compartment by a process akin to MHC-II presentation. Pioneering work from the Harding laboratory showed that cross-presentation can be achieved in macrophages in the absence of functional TAP transporters and in a way that is insensitive to pharmacological inhibition of the proteasome (155). Later on, TAP-independent crosspresentation was shown to involve cathepsin S (156). It is generally admitted that the vacuolar form of cross-presentation is associated with high levels of antigen delivered in the endocytic pathway. Whether this might be a physiological way to handle cellular antigens, or perhaps the most abundant of them, remains to be established.

\section{Antigen Retention in the Endocytic Pathway of Cross-Presenting cDCs}

There is a wealth of evidence supporting the notion that limited endo-lysosomal proteolysis of engulfed antigens promotes their efficient cross-presentation by cDCs. Overall, limited endolysosomal proteolysis is associated with the DC lineage $(157,158)$. An elegant study by Delamarre et al. showed that GM-CSF DCs, splenic DCs and DCs from lymphoid organs expressed lower levels of lysosomal proteases than in vitro differentiated macrophages, splenic, lymphoid, and peritoneal macrophages. This correlates with a decrease in the capacity of DCs to degrade soluble proteins in vitro and in vivo (158). These findings were extended to human DCs derived from $\mathrm{CD} 34^{+}$hematopoietic progenitor cells or isolated from peripheral blood, which, in comparison with macrophages, are also protease poor (159). Overall, human cDCs express less cathepsin B, L, and S than moDCs, and both murine and human cDC2s express slightly more proteases than CDC1s $(140,142)$.

In addition to their low content in proteases, DCs also limit the activity of acid-dependent lysosomal proteases by maintaining a relatively alkaline endocytic pathway. Pharmacological inhibition of endocytic acidification by treatment with cloroquine, ammonium chloride, or protease inhibitors boosts cross-presentation of endocytosed proteins in human moDCs or cDC2 $(141,160$, 161). The relatively high endo/phagosomal $\mathrm{pH}$ of DCs is mainly explained by two factors.

First, in immature DCs an important fraction of the cytosolic subunits of the vacuolar ATPase (V1 sector) appears dissociated from the trans-membrane $\mathrm{V} 0$ sector. As a proper assembly of both subunits is needed for the function of the V-ATPase, the higher $\mathrm{pH}$ can be partially explained by a deficient transport of protons to the lumen of the lysosome (162). Activation of DC maturation in vitro promotes the assembly of the complex and its role in luminal acidification (162). Interestingly, the phosphatidylinositol 3-kinase/ mTOR pathway has recently been identified as an upstream regulator of the V-ATPase assembly during DC activation (163).

Second, the NADPH oxidase regulates phagosomal acidification in murine and human GM-CSF moDCs and CD8 $\alpha^{+} \mathrm{cDC} 1 \mathrm{~s}$ (164-166). The NOX2 complex is recruited to the phagosomal membrane and produces reactive oxygen species (ROS) that activates proton consumption and induces lumenal alkalinization $(164,166)$. As a consequence, both mice and human DCs deficient in functional NADPH oxidase have reduced cross-presentation (164-166). Recruitment of the Rac2 GTPase to phagosomes would support cDC1 NADPH oxidase at phagosomal membranes (166). The relevance of the Rac2/NAPDH oxidase complex on the crosspresentation of cell-associated antigens in vivo remains to be tested.

Another level of regulation of the phagocytic pathway involves the endoplasmic reticulum (ER)-resident $47 \mathrm{kDa}$ interferoninducible GTPase, Irgm3, and its Perlipin2/Adrp partner (167). Irgm 3 is expressed in both mouse $\mathrm{CDC} 1$ and $\mathrm{cDC} 2 \mathrm{~s}$ subsets and further induced upon TLR3 activation (167). Irgm3 associates with the ER and lipid bodies (LBs) of DCs where it directly interacts with the LB coat protein Perilipin2 (167). The depletion of Irgm 3 or Perilipin 2 decreases the number of LBs at steady state and abrogates their induction upon $\mathrm{IFN}_{\mathrm{\gamma}}$ and poly:IC treatments, whereas Irgm 3 over-expression does the contrary. Importantly, 
the splenic $\mathrm{cDC} 1 \mathrm{~s}$ show higher steady-state levels of LBs than the cDC2s (167), which can be explained by higher Perilipin2 levels $(53,140,167)$. The reduction of LBs by pharmacological treatments or genetic inactivation of Perilipin 2 or Irgm 3 inhibits cross-presentation by mouse $\mathrm{cDC} 1$, including the cross-presentation of cell-associated antigens in vivo (167). Interestingly, $\operatorname{Irgm3^{-/-}}$ moDCs have an accelerated phagolysosomal maturation as compared to their WT counterparts. The mechanisms underlying this effect are unknown, but a direct association between LB and the phagosomal membranes has been demonstrated in moDCs (167) and other cells (168). Interestingly, the NOX2 complex protein gp $91^{\text {phox }}$ controls the recruitment of the cytosolic phospholipase A2 (PLA2) and LBs themselves to phagosomes $(169,170)$. An interesting hypothesis is that LBs might provide a lipid source for the formation of the NOX2 activator arachidonic acid (AA) in a PLA2-dependent manner $(171,172)$. Therefore, it is conceivable that NOX2 and LBs might cooperate to regulate oxidative metabolism with consequences for antigen proteolysis and, in fine, cross-presentation.

Finally, "antigen retention" early endocytic compartments segregated from the normal progression of endosomes to lysosomes have been described in DC lines after macro-pinocytosis or antibodymediated uptake of soluble antigens $(173,174)$. Antigen retention compartments might provide a long-term source of antigen for the continuous loading of MHC-I receptors $(173,174)$. Burgdorf and Kurts found that mannose receptor targeting, but not fluid phase uptake, leads to prolonged antigen accumulation of antigen in antigen retention compartments with slow rates of maturation to lysosomes (175-177). This compartment is accessible to TAP and MHC class I loading complex upon TLR stimulation (176) (see below). Moreover, they can acquire the MHC class I antigen trimming enzyme insulin responsive aminopeptidase (IRAP), since mannose receptor endosomes partially overlap with the vesicular compartment described by IRAP, an enzyme that interacts with MHC class I molecules and performs antigen trimming in endosomes, in a model of proteasome-dependent cross-presentation (178). In the absence of IRAP, in vivo cross-presentation of antigens targeted to mannose receptors is compromised, underlining the functional relevance of mannose receptor and IRAP endosomes overlapping (178). However, there is a controversy regarding the relevance of this pathway for the uptake of OVA by spleen cDCs, specifically $\operatorname{cDC1}(99,177,179)$. More generally, one might wonder if mannose receptor-targeted $\mathrm{IRAP}^{+}$endosomes are of relevance regarding the cross-presentation and routing of cell-associated antigens during the engulfment of dead cells, which might be processed in the phagosome. In the phagosome, MHC class I ligand production is usually the result of a cooperative action of cytosolic proteasome, ER-resident trimming aminopeptidases and IRAP (180).

Dendritic cells receptors involved in dead cell uptake or sensing might regulate phagosome maturation to promote antigen retention for cross-presentation. In support of this notion, Sancho et al. have shown that $C l e c 9 a^{-/} \mathrm{cDC} 1 \mathrm{~s}$ have reduced cross-presentation of cell-associated antigen, in vitro and in vivo (125). By contrast, Clec $9 a^{-/-}$cDC1s normally cross-present antigen coupled to latex beads suggesting a cargo-specific process $(125,181)$. Ligation of danger-associated molecular patterns found in dead cells like filamentous actin might act as a regulator of the trafficking of dead cells in cDC1s $(126,182)$. Supporting this notion, DNGR1/Clec9a deficiency inhibits the accumulation of Rab5a and Rab11 markers to the dead cell phagosome (182). A quantitative analysis of dead cell-containing phagosomes has been performed by the Janssen laboratory $(183,184)$. These authors have shown that cell remnants captured by murine splenic $\mathrm{cDC} 1 \mathrm{~s}$, in particular a CD8 $\alpha^{-} \mathrm{Clec} 9 \mathrm{a}^{+}$ subset of cDC1s, have a smaller size and a longer persistence (up to $20 \mathrm{~h})$ as compared to the ones captured by spleen cDC2 $(183,184)$. Interestingly, endocytic compartments carrying dead cell debris remains poorly acidified and retain early endocytic markers such EEA1 $(183,184)$. These in vitro data are consistent with the fact that cell debris carrying intact GFP from infected cells engulfed in the lung could still be found in non-infected, phagocytic cDC1 having reached lung draining lymph nodes (15). Overall, antigen retention by migratory $\mathrm{cDCs}$ might enable the coordination of antigen presentation/cross-presentation with migration from antigen sampling sites (tissues) to the $\mathrm{T}$ cell areas of the lymph nodes. However, the nature of antigen retention compartments and the mechanisms regulating the access of cell-associated antigens to this compartment remains to be addressed in more detail.

\section{The Translocation of Phagosomal Antigens Inside the Cytosol in cDCs Subsets}

Initial work from the Watts laboratory identified growth factorinduced macro-pinocytosis as an efficient, actin-dependent, endocytic process leading to the export of captured antigens to the cytosol (185). Importantly, immature moDCs and cDCs were found to display constitutively active macro-pinocytosis mediating the delivery of exogenous antigens to the cytosol for cross-presentation $(186,187)$. Later on, morphological evidence of cytosolic access of protein antigens targeted to Fc-receptors and soluble dextrans were reported in DCs $(188,189)$. Importantly, antigen transport to the cytosol was found to be specific for DCs since it was not observed in macrophages (188).

Is the cytosolic pathway for cross-presentation active in specific cDCs subsets in vivo? Plamowski et al. have shown in vivo that cross-priming against an HY-encoded minor histocompatibility antigen is reduced in mice deficient for some immuneproteasome subunits $\left(\mathrm{LMP7}^{-/-}\right)(190)$. This study represents a unique in vivo, indirect genetic demonstration of the involvement of the cytosolic pathway in the cross-priming of $\mathrm{CD}^{+} \mathrm{T}$ cells toward cell-associated antigens. The most compelling in vivo direct evidence of cytosolic export comes from a work in which mice were injected with soluble cytochrome $c$ protein. Following this treatment, Apaf-1-dependent apoptosis was used as a readout of cytochrome $c$ release to the cytosol (191). Lin et al. observed a selective depletion of spleen $\mathrm{cDC} 1 \mathrm{~s}\left(\mathrm{CD} 8^{+} \mathrm{CD} 103^{+}\right)$upon cytochrome $c$ depletion. These experiments suggest that $\mathrm{cDC} 1 \mathrm{~s}$ might be endowed with a specific ability to release antigen from the endocytic pathway inside the cytosol. Do these findings translate to humans cDC1s? This is not completely clear. Indeed, cross-presentation by human $\mathrm{CDC} 1$ s is largely blocked by inhibitors of the proteasome supporting the use of soluble antigens in the cytosolic pathway $(48,108)$. Segura et al. have used an elegant 
$\beta$-lactamase-based fluorescent assay to monitor the delivery of soluble proteins to the cytosol of DCs (108). Using this assay they found that $\mathrm{cDC} 1, \mathrm{cDC} 2$, and $\mathrm{pDCs}$ (but not $\mathrm{CD} 14^{+}$macrophages) all perform the cytosolic export of endocytosed antigens efficiently (108). This elegant assay might selectively visualize early events of translocation, before possible destabilization of the enzyme by endo-lysosomal proteolysis. Distinct conclusions were obtained by Cohn et al. who report that $\mathrm{CDC} 1 \mathrm{~s}$, but not $\mathrm{cDC} 2 \mathrm{~s}$, do crosspresent antigens when they access late endocytic compartments (142). This was exemplified with fusion-defective viruses, Listeriaencoded antigens from translocation-defective $\left(\mathrm{LLO}^{-}\right)$strains or DEC205 receptor targeting (142). An interpretation of these important findings is that cytosolic cross-presentation could be mediated by two pathways: an early endocytic cross-presentation pathway which is functional in both $\mathrm{CDC} 1$ and $\mathrm{CDC} 2 \mathrm{~s}$, and a late endocytic pathway more specifically associated with $\mathrm{cDC} 1 \mathrm{~s}$ $(141,142)$. The later process could imply the existence of specific lysosomal mechanisms for efficient antigen export only present in the $\mathrm{cDC} 1$. Alternatively, lysosomal processing of antigens could occur more slowly in the $\mathrm{cDC} 1$ allowing their cytosolic export before complete lumenal degradation. Further mechanistic studies are needed to decipher whether the translocation of antigens to the cytosol is an active process associated with the endocytic membranes of $\mathrm{cDCs}$ or a passive process associated with the accumulation of non-degraded proteins in endocytic compartments. In support of the latter, experimental inhibition of protein degradation leads to improved transport in the cytosol $(160,189)$.

\section{A Role for Endoplasmic Reticulum-Associated Degradation in the Translocation of Phagocytic Antigens into the Cytosol by cDCs}

With the existence of a phagosome-to-cytosol pathway being well accepted, the mechanisms underlying the translocation of antigens across the endocytic membrane are the focus of intense investigations. In multiple experimental systems, enzymatically active proteins have been found in cytosolic extracts, suggesting that the cytosolic translocation might not necessarily involve protein unfolding. The disruption of endocytic membranes might be put forward as a hypothesis. Indeed, experimental osmotic disruption of endo-lysosomes is sufficient to trigger crosspresentation of exogenous antigens (192). However, disruption of endo-lysosomal membranes is associated with the induction of cell death by lysosomal proteases [e.g., cathepsin (193)]. A popular hypothesis explaining the transport of antigens to the cytosol involves the access of endocytic antigens to translocation processes associated with the ER. The active transport of ER-associated ill-folded proteins inside the cytosol for proteasomal degradation (ERAD) in particular has been speculated to regulate cross-presentation by MHC-I. The channel protein sec61, which has been involved in the export of mis-folded proteins to the cytosol as part of the ERAD machinery $(194,195)$ is present in the phagosomal membrane together with other ER markers (196-198). More recent studies have shown that the ER-resident SNARE sec22b is directly involved in the recruitment of ER membranes to the phagosome, possibly favoring the onset of ERAD of luminal antigens (199). The specific involvement of sec61 in the translocation of peptides to the cytosol has been demonstrated in vitro using assays in which the export of radiolabeled peptides from microsomes was inhibited in the presence of the sec61 inhibitor Pseudomonas aeruginosa exotoxin A (ExoA) (200). The knockdown of sec61 in the DC2.4 moDCs line decreased cross-presentation of soluble OVA supporting that it is a role for sec61 in cross-presentation (201). A more recent paper has demonstrated that sec61 is recruited to endosomes carrying OVA antigen and that such recruitment depends on TRIF signaling. Inhibition of sec61 release from the ER to the endosomes using a specific antibody against sec61 fused to an ER retention sequence impairs cross-presentation and antigen export to the cytosol in DC2.4 and BMDCs (202).

However, the involvement of sec61 in cross-presentation by the human DC subsets is still controversial, as it has been reported that depletion of sec61 or the use of ExoA did not have any impact in cross-presentation of an HLA-A2-restricted epitope by human DC differentiated from monocytes (203). Another member of the ERAD machinery related to cytosolic export of antigens during cross-presentation is the soluble AAA ATPase p97, which is thought to provide the required energy for the passage of proteins through ER membranes (204). The addition of purified recombinant p97, but not a dominant negative form of the protein, is enough to promote the export of proteins from purified luciferase-loaded phagosomes even in the absence of other cytosolic factors (205). In functional terms, cells expressing a dominant negative form of p97 show a decrease in cross-presentation of soluble OVA (205). In vivo evidence of ER-associated process for antigen transport to the cytosol is provided by a mouse knockout for the heat shock protein 90 (HSP90) (206). HSP90 is a chaperone associated with the ERAD complex on the cytosolic side of the ER, and its knockdown in the DC-like cell line KG-1 impairs the refolding of proteins that have gained access to the cytosol (207). Soluble cytochrome $c$ does not induce apoptosis in BMDCs from HSP90 $\alpha$-null indicating that HSP90 might participate to the cytosolic export of soluble proteins (208). Importantly, in vivo apoptosis of splenic cDC1s induced by cytochrome $c$ injection is also impaired in HSP90 $\alpha$-null mice, and cross-priming of splenic $\mathrm{CD}^{+}$T cells isolated from HSP90 $\alpha$-null mice after immunization with OVA-coated splenocytes is reduced (206).

Finally, mice lacking the $\mathrm{\gamma}$-interferon-inducible lysosomal thiol reductase (GILT) - which is present in phagosomes and lysosomes - are deficient in their ability to cross-present $\mathrm{gB}$, an HSV-1 glycoprotein that contains five disulfide bonds. As the cytosolic export of ERAD substrates containing disulfide bonds requires their prior reduction and unfolding, it is feasible that GILT regulates cross-presentation by facilitating an ERADdependent transport of reduced antigens carrying disulfide bonds to the cytosol (209).

Of note, soluble antigens might also enter ERAD after having reached ER lumen by retrograde transport. This possibility is supported by in vitro studies reporting that a significant part of soluble OVA captured by moDCs actually reaches the ER lumen (210). Whether this is relevant for cell-associated antigens in cDCs remains to be established. 
In summary, despite the incomplete understanding of the cellular machinery required for cytosolic transport of endocytic antigens, there is evidence indicating that $\mathrm{cDCs}$ have developed specific features to enhance the efficiency of cytosolic export.

\section{Where Does MHC Class I Loading Occur During Cross-Presentation?}

Early experiments showing that cross-presentation could be inhibited by treatments like brefeldin A $(149,186)$, which blocks the anterograde transport of ER-synthesized proteins through the secretory pathway, led to the initial idea that MHC-I loading took place at the ER. Subsequent studies have demonstrated a fusion between the ER membrane and the phagosome at an early phagocytic step, indicating that the ER can provide a source of membrane to the phagosme for the loading of MHC-I molecules (196). Consistent with this idea, TAP, tapasin, calreticulin, Erp57, and the heavy chain of MHC class I are detected in purified early phagosomes from DCs (197). More importantly, MHC-I loaded with peptide was more abundant in phagosomes containing OVA-coupled beads, which indicates a direct loading of MHC-I molecules at the phagosome rather than a delivery of MHC-I loaded molecules to the phagosome (197). Depletion of sec22b impairs the recruitment of ER proteins like TAP2, tapasin, and calreticulin to the phagosome and cross-presentation by moDCs (199). These results point to a role of $\sec 22$ in the recruitment of essential components of the peptide-loading complex to the phagosome, the delivery of MHC-I to the phagosome does not seem to be altered by the depletion of sec22b. This is consistent with the intracellular localization of MHC-I, which at steady state is mainly found at the plasma membrane and the recycling endosome but not at the ER (211). Therefore, it is feasible to consider that part of the MHC-I loading might also occur at an endosomal compartment. Supporting this idea, the Jefferies laboratory has shown that murine DCs expressing mutated forms of the MHC-I receptor lacking a tyrosine residue of its cytoplasmic domain have an impaired MHC-I distribution and a reduction/loss in crosspresentation (212). The MHC-II chaperone might also be involved in an interaction with MHC-I and participates in the diversion of MHC-I toward endo-lysosomes (213). Whereas these results indicate that the loading of MHC-I molecules also occurs at the late endosome/lysosome, it is less clear if MHC-I loading at the endosomal compartment requires components of the cytosolic pathway or exclusively relies in the vacuolar pathway. For further discussion on MHC-I trafficking and its relevance to cross-presentation, see the accompanying review by Adiko Assi et al. in this issue.

Kurts and Burgdorf have reported that TLR engagement stimulates the recruitment of TAP and MHC-I to a mannose receptorcontaining population of early endosomes in murine moDCs, specifically. Specific inhibition of TAP in early endosomes using the viral TAP luminal inhibitor US6 fused to transferrin inhibited cross-presentation but not direct presentation (which relies on ER-associated TAP) (176). By contrast, a recent study describes ERGIC-derived and sec22b-dependent TAP recruitment to bacteria-containing phagosomes as a constitutive mechanism, independent of TLR activation (214). Alternatively, TLR activation regulates cross-presentation by promoting the transport of
MHC-I molecules from a recycling endosomal compartment to the phagosome. This process is mediated by the phosphorylation of SNAP23 via Myd88-dependent IKK2 activation and requires the recycling endosome GTPase Rab11 (214). Interestingly, mouse and human cDC1 cells express higher levels of Rab11, as compared to their $\mathrm{cDC} 2 \mathrm{~s}$ counterparts (71), a feature that needs further exploration to determine whether it is relevant or not for the cross-presentation of cell-associated antigens.

However, there is no doubt that cross-presentation can take place in steady state, non-activated DCs. Accordingly, DCs deficient in TLR signaling ( $\mathrm{Myd} 88^{-/-} / \mathrm{TRIF}^{-/-}$) do not show any major defects in cross-presentation (215). However, TLR3 is selectively associated with both mouse and human cDC1s (37, 47-49, 53). Accordingly, synthetic or viral agonists of the TLR3TRIF pathway in particular, when associated with dead cells provide a strong co-activation stimulus for the cross-priming of $\mathrm{CD}^{+} \mathrm{T}$ cells specific for cell-associated antigens $(89,216)$. A more recent paper has shown that in $\mathrm{Batf3}^{-/-}$lacking the $\mathrm{CD} 103^{+}$ DCs CTL responses upon soluble OVA immunization and TLR3 stimulation by polyIC are impaired. Interestingly, the dependence on TLR3 expression was exclusive of cell-associated antigen, as in $\mathrm{TLR}^{-/-}$mice immunization with soluble OVA together with polyIC induced strong CTL responses depending on the dsRNA sensors MDA5/RIG-I (217).

It is rather difficult to disentangle the effects of TLR signaling on DC activation from the ones associated with antigen crosspresentation by MHC class I. Nevertheless, multiple studies suggest that TLR signaling, especially by intracellular TLRs (TLR3, 7 , and 9) improve cross-presentation $(218,219)$.

TLR3, 7, and 9 rely on the Unc93b for their transport from ER to the endocytic pathway independently from the Golgi apparatus (220-222). Interestingly, DCs from Unc93b mutant mice were initially reported to be deficient in their ability to perform crosspresentation of cell-associated antigens (220). These findings have been challenged by a recent study that did not identify differences between wild-type and Unc93b-mutated DCs (223). Further quantitative studies might clarify this point but it is tempting to speculate that Unc93b might have a TLR-independent effect on the trafficking enabling cross-presentation, perhaps by regulating the transport of the peptide-loading complex outside of the secretory pathway.

\section{Concluding Remarks}

The physiological relevance of the cross-presentation of cell-associated antigens is well acknowledged. Whether cross-presentation by MHC-I is a passive consequence of limited phagolysosomal digestion of dead cell bodies or something more specifically regulated remains to be understood. The identification of the molecular machineries controlling cross-presentation in cDCs should shed some light on this process.

\section{Acknowledgments}

The authors thanks J. Helft for critical reading of the manuscript. This work is supported by MRC MR/K01241X/1 and KHP R140806 research grants. PG is a CNRS investigator. 


\section{References}

1. Bevan MJ. Cross-priming for a secondary cytotoxic response to minor $H$ antigens with H-2 congenic cells which do not cross-react in the cytotoxic assay. J Exp Med (1976) 143(5):1283-8. doi:10.1084/jem.143.5.1283

2. Bevan MJ. Minor $\mathrm{H}$ antigens introduced on $\mathrm{H}-2$ different stimulating cells cross-react at the cytotoxic T cell level during in vivo priming. J Immunol (1976) 117(6):2233-8.

3. Carbone FR, Bevan MJ. Class I-restricted processing and presentation of exogenous cell-associated antigen in vivo. J Exp Med (1990) 171(2):377-87. doi:10.1084/jem.171.2.377

4. Gooding LR, Edwards CB. H-2 antigen requirements in the in vitro induction of SV40-specific cytotoxic T lymphocytes. J Immunol (1980) 124(3):1258-62.

5. Huang AY, Golumbek P, Ahmadzadeh M, Jaffee E, Pardoll D, Levitsky H. Role of bone marrow-derived cells in presenting MHC class I-restricted tumor antigens. Science (1994) 264(5161):961-5. doi:10.1126/science.7513904

6. Sigal LJ, Crotty S, Andino R, Rock KL. Cytotoxic T-cell immunity to virus-infected non-haematopoietic cells requires presentation of exogenous antigen. Nature (1999) 398(6722):77-80. doi:10.1038/18038

7. Heath WR, Carbone FR. Cross-presentation in viral immunity and self-tolerance. Nat Rev Immunol (2001) 1(2):126-34. doi:10.1038/35100512

8. Kurts C, Heath WR, Carbone FR, Allison J, Miller JF, Kosaka H. Constitutive class I-restricted exogenous presentation of self antigens in vivo. J Exp Med (1996) 184(3):923-30. doi:10.1084/jem.184.3.923

9. Kurts C, Kosaka H, Carbone FR, Miller JF, Heath WR. Class I-restricted cross-presentation of exogenous self-antigens leads to deletion of autoreactive CD8(+) T cells. J Exp Med (1997) 186(2):239-45. doi:10.1084/ jem.186.12.2057

10. Bonifaz L, Bonnyay D, Mahnke K, Rivera M, Nussenzweig MC, Steinman RM. Efficient targeting of protein antigen to the dendritic cell receptor DEC-205 in the steady state leads to antigen presentation on major histocompatibility complex class I products and peripheral CD8+ T cell tolerance. J Exp Med (2002) 196(12):1627-38. doi:10.1084/jem.20021598

11. Luckashenak N, Schroeder S, Endt K, Schmidt D, Mahnke K, Bachmann $\mathrm{MF}$, et al. Constitutive crosspresentation of tissue antigens by dendritic cells controls CD8+ T cell tolerance in vivo. Immunity (2008) 28(4):521-32. doi:10.1016/j.immuni.2008.02.018

12. Gallegos AM, Bevan MJ. Central tolerance to tissue-specific antigens mediated by direct and indirect antigen presentation. J Exp Med (2004) 200(8):1039-49. doi:10.1084/jem.20041457

13. Albert ML, Sauter B, Bhardwaj N. Dendritic cells acquire antigen from apoptotic cells and induce class I-restricted CTLs. Nature (1998) 392(6671):86-9. doi: $10.1038 / 32183$

14. Ramirez MC, Sigal LJ. Macrophages and dendritic cells use the cytosolic pathway to rapidly cross-present antigen from live, vaccinia-infected cells. J Immunol (2002) 169(12):6733-42. doi:10.4049/jimmunol.169.12.6733

15. Helft J, Manicassamy B, Guermonprez P, Hashimoto D, Silvin A, Agudo J, et al. Cross-presenting CD103+ dendritic cells are protected from influenza virus infection. J Clin Invest (2012) 122(11):4037-47. doi:10.1172/ JCI60659

16. Bellone M, Iezzi G, Rovere P, Galati G, Ronchetti A, Protti MP, et al. Processing of engulfed apoptotic bodies yields $\mathrm{T}$ cell epitopes. J Immunol (1997) 159(11):5391-9.

17. Li M, Davey GM, Sutherland RM, Kurts C, Lew AM, Hirst C, et al. Cellassociated ovalbumin is cross-presented much more efficiently than soluble ovalbumin in vivo. JImmunol (2001) 166(10):6099-103. doi:10.4049/ jimmunol.166.5.3122

18. Kurts C, Miller JF, Subramaniam RM, Carbone FR, Heath WR. Major histocompatibility complex class I-restricted cross-presentation is biased towards high dose antigens and those released during cellular destruction. J Exp Med (1998) 188(2):409-14. doi:10.1084/jem.188.2.415

19. Iyoda T, Shimoyama S, Liu K, Omatsu Y, Akiyama Y, Maeda Y, et al. The CD8+ dendritic cell subset selectively endocytoses dying cells in culture and in vivo. J Exp Med (2002) 195(10):1289-302. doi:10.1084/jem.20020161

20. Trinite B, Voisine C, Yagita H, Josien R. A subset of cytolytic dendritic cells in rat. J Immunol (2000) 165(8):4202-8. doi:10.4049/jimmunol.165.8.4202

21. Trinite B, Chauvin C, Peche H, Voisine C, Heslan M, Josien R. Immature CD4$\mathrm{CD} 103+$ rat dendritic cells induce rapid caspase-independent apoptosis-like cell death in various tumor and nontumor cells and phagocytose their victims. J Immunol (2005) 175(4):2408-17. doi:10.4049/jimmunol.175.4.2408

22. Chauvin C, Josien R. Dendritic cells as killers: mechanistic aspects and potential roles. J Immunol (2008) 181(1):11-6. doi:10.4049/jimmunol.181.1.11

23. Norbury CC, Basta S, Donohue KB, Tscharke DC, Princiotta MF, Berglund $\mathrm{P}$, et al. CD8+ T cell cross-priming via transfer of proteasome substrates. Science (2004) 304(5675):1318-21. doi:10.1126/science.1096378

24. Shen L, Rock KL. Cellular protein is the source of cross-priming antigen in vivo. Proc Natl Acad Sci U S A (2004) 101(9):3035-40. doi:10.1073/pnas. 0402602101

25. Wolkers MC, Brouwenstijn N, Bakker AH, Toebes M, Schumacher TN. Antigen bias in T cell cross-priming. Science (2004) 304(5675):1314-7. doi:10.1126/science.1096268

26. Ma X, Serna A, Xu RH, Sigal LJ. The amino acid sequences flanking an antigenic determinant can strongly affect MHC class I cross-presentation without altering direct presentation. JImmunol (2009) 182(8):4601-7. doi:10.4049/jimmunol.0803806

27. Nussenzweig MC, Steinman RM. Contribution of dendritic cells to stimulation of the murine syngeneic mixed leukocyte reaction. J Exp Med (1980) 151(5):1196-212. doi:10.1084/jem.151.5.1196

28. Nussenzweig MC, Steinman RM, Gutchinov B, Cohn ZA. Dendritic cells are accessory cells for the development of anti-trinitrophenyl cytotoxic $\mathrm{T}$ lymphocytes. J Exp Med (1980) 152(4):1070-84. doi:10.1084/jem.152.4.1070

29. Jung S, Unutmaz D, Wong P, Sano G, De los Santos K, Sparwasser T, et al. In vivo depletion of CD11c+ dendritic cells abrogates priming of CD8 $+\mathrm{T}$ cells by exogenous cell-associated antigens. Immunity (2002) 17(2):211-20. doi:10.1016/S1074-7613(02)00365-5

30. Meredith MM, Liu K, Darrasse-Jeze G, Kamphorst AO, Schreiber HA, Guermonprez P, et al. Expression of the zinc finger transcription factor zDC (Zbtb46, Btbd4) defines the classical dendritic cell lineage. J Exp Med (2012) 209(6):1153-65. doi:10.1084/jem.20112675

31. Schreiber HA, Loschko J, Karssemeijer RA, Escolano A, Meredith MM, Mucida D, et al. Intestinal monocytes and macrophages are required for $\mathrm{T}$ cell polarization in response to Citrobacter rodentium. J Exp Med (2013) 210(10):2025-39. doi:10.1084/jem.20130903

32. Satpathy AT, Wumesh KC, Albring JC, Edelson BT, Kretzer NM, Bhattacharya D, et al. Zbtb46 expression distinguishes classical dendritic cells and their committed progenitors from other immune lineages. J Exp Med (2012) 209(6):1135-52. doi:10.1084/jem.20120030

33. McKenna HJ, Stocking KL, Miller RE, Brasel K, De Smedt T, Maraskovsky E, et al. Mice lacking flt3 ligand have deficient hematopoiesis affecting hematopoietic progenitor cells, dendritic cells, and natural killer cells. Blood (2000) 95(11):3489-97.

34. Waskow C, Liu K, Darrasse-Jeze G, Guermonprez P, Ginhoux F, Merad M, et al. The receptor tyrosine kinase Flt3 is required for dendritic cell development in peripheral lymphoid tissues. Nat Immunol (2008) 9(6):676-83. doi:10.1038/ni.1615

35. MartIn-Fontecha A, Sebastiani S, Hopken UE, Uguccioni M, Lipp M, Lanzavecchia A, et al. Regulation of dendritic cell migration to the draining lymph node: impact on T lymphocyte traffic and priming. J Exp Med (2003) 198(4):615-21. doi:10.1084/jem.20030448

36. Miller JC, Brown BD, Shay T, Gautier EL, Jojic V, Cohain A, et al. Deciphering the transcriptional network of the dendritic cell lineage. Nat Immunol (2012) 13(9):888-99. doi:10.1038/ni.2370

37. Crozat K, Guiton R, Contreras V, Feuillet V, Dutertre CA, Ventre E, et al. The XC chemokine receptor 1 is a conserved selective marker of mammalian cells homologous to mouse CD8alpha+ dendritic cells. J Exp Med (2010) 207(6):1283-92. doi:10.1084/jem.20100223

38. Dalod M, Chelbi R, Malissen B, Lawrence T. Dendritic cell maturation: functional specialization through signaling specificity and transcriptional programming. EMBOJ (2014) 33(10):1104-16. doi:10.1002/embj.201488027

39. Guilliams M, Ginhoux F, Jakubzick C, Naik SH, Onai N, Schraml BU, et al. Dendritic cells, monocytes and macrophages: a unified nomenclature based on ontogeny. Nat Rev Immunol (2014) 14(8):571-8. doi:10.1038/nri3712

40. Merad M, Sathe P, Helft J, Miller J, Mortha A. The dendritic cell lineage: ontogeny and function of dendritic cells and their subsets in the steady state and the inflamed setting. Annu Rev Immunol (2013) 31:563-604. doi:10.1146/ annurev-immunol-020711-074950 
41. Bursch LS, Wang L, Igyarto B, Kissenpfennig A, Malissen B, Kaplan DH, et al. Identification of a novel population of langerin + dendritic cells. J Exp Med (2007) 204(13):3147-56. doi:10.1084/jem.20071966

42. Ginhoux F, Collin MP, Bogunovic M, Abel M, Leboeuf M, Helft J, et al. Bloodderived dermal langerin + dendritic cells survey the skin in the steady state. $J$ Exp Med (2007) 204(13):3133-46. doi:10.1084/jem.20071733

43. Poulin LF, Henri S, de Bovis B, Devilard E, Kissenpfennig A, Malissen B. The dermis contains langerin+ dendritic cells that develop and function independently of epidermal Langerhans cells. J Exp Med (2007) 204(13):3119-31. doi:10.1084/jem.20071724

44. Kissenpfennig A, Henri S, Dubois B, Laplace-Builhe C, Perrin P, Romani N, et al. Dynamics and function of Langerhans cells in vivo: dermal dendritic cells colonize lymph node areas distinct from slower migrating Langerhans cells. Immunity (2005) 22(5):643-54. doi:10.1016/j.immuni.2005.04.004

45. GeurtsvanKessel $\mathrm{CH}$, Willart MA, Bergen IM, van Rijt LS, Muskens F, Elewaut D, et al. Dendritic cells are crucial for maintenance of tertiary lymphoid structures in the lung of influenza virus-infected mice. J Exp Med (2009) 206(11):2339-49. doi:10.1084/jem.20090410

46. Henri S, Poulin LF, Tamoutounour S, Ardouin L, Guilliams M, de Bovis B, et al. CD207+ CD103+ dermal dendritic cells cross-present keratinocyte-derived antigens irrespective of the presence of Langerhans cells. J Exp Med (2010) 207(1):189-206. doi:10.1084/jem.20091964

47. Bachem A, Guttler S, Hartung E, Ebstein F, Schaefer M, Tannert A, et al. Superior antigen cross-presentation and XCR1 expression define human CD11c+CD141+ cells as homologues of mouse CD8+ dendritic cells. J Exp Med (2010) 207(6):1273-81. doi:10.1084/jem.20100348

48. Jongbloed SL, Kassianos AJ, McDonald KJ, Clark GJ, Ju X, Angel CE, et al. Human CD141+ (BDCA-3)+ dendritic cells (DCs) represent a unique myeloid DC subset that cross-presents necrotic cell antigens. J Exp Med (2010) 207(6):1247-60. doi:10.1084/jem.20092140

49. Poulin LF, Salio M, Griessinger E, Anjos-Afonso F, Craciun L, Chen JL, et al. Characterization of human DNGR-1+ BDCA3+ leukocytes as putative equivalents of mouse CD8alpha+ dendritic cells. J Exp Med (2010) 207(6):1261-71. doi:10.1084/jem.20092618

50. Hildner K, Edelson BT, Purtha WE, Diamond M, Matsushita H, Kohyama M, et al. Batf3 deficiency reveals a critical role for CD8alpha+ dendritic cells in cytotoxic T cell immunity. Science (2008) 322(5904):1097-100. doi:10.1126/ science.1164206

51. Poulin LF, Reyal Y, Uronen-Hansson H, Schraml BU, Sancho D, Murphy $\mathrm{KM}$, et al. DNGR-1 is a specific and universal marker of mouse and human Batf3-dependent dendritic cells in lymphoid and nonlymphoid tissues. Blood (2012) 119(25):6052-62. doi:10.1182/blood-2012-01-406967

52. Edwards AD, Diebold SS, Slack EM, Tomizawa H, Hemmi H, Kaisho T, et al. Toll-like receptor expression in murine DC subsets: lack of TLR7 expression by CD8 alpha+ DC correlates with unresponsiveness to imidazoquinolines. Eur J Immunol (2003) 33(4):827-33. doi:10.1002/eji.200323797

53. Edwards AD, Chaussabel D, Tomlinson S, Schulz O, Sher A, Reis e Sousa C. Relationships among murine $\mathrm{CD} 11 \mathrm{c}$ (high) dendritic cell subsets as revealed by baselinegeneexpression patterns. Immunol(2003) 171(1):47-60.doi:10.4049/ jimmunol.171.1.47

54. Hemont C, Neel A, Heslan M, Braudeau C, Josien R. Human blood mDC subsets exhibit distinct TLR repertoire and responsiveness. J Leukoc Biol (2013) 93(4):599-609. doi:10.1189/jlb.0912452

55. Persson EK, Uronen-Hansson H, Semmrich M, Rivollier A, Hagerbrand K, Marsal J, et al. IRF4 transcription-factor-dependent CD103(+)CD11b(+) dendritic cells drive mucosal Thelper 17 cell differentiation. Immunity (2013) 38(5):958-69. doi:10.1016/j.immuni.2013.03.009

56. Schlitzer A, McGovern N, Teo P, Zelante T, Atarashi K, Low D, et al. IRF4 transcription factor-dependent $\mathrm{CD} 11 \mathrm{~b}+$ dendritic cells in human and mouse control mucosal IL-17 cytokine responses. Immunity (2013) 38(5):970-83. doi:10.1016/j.immuni.2013.04.011

57. Tamura T, Tailor P, Yamaoka K, Kong HJ, Tsujimura H, O'Shea JJ, et al. IFN regulatory factor- 4 and -8 govern dendritic cell subset development and their functional diversity. JImmunol (2005) 174(5):2573-81. doi:10.4049/ jimmunol.174.5.2573

58. Vander Lugt B, Khan AA, Hackney JA, Agrawal S, Lesch J, Zhou M, et al. Transcriptional programming of dendritic cells for enhanced MHC class II antigen presentation. Nat Immunol (2014) 15(2):161-7. doi:10.1038/ ni. 2795
59. Naik SH, Sathe P, Park HY, Metcalf D, Proietto AI, Dakic A, et al. Development of plasmacytoid and conventional dendritic cell subtypes from single precursor cells derived in vitro and in vivo. Nat Immunol (2007) 8(11):1217-26. doi:10.1038/ni1522

60. Onai N, Obata-Onai A, Schmid MA, Ohteki T, Jarrossay D, Manz MG. Identification of clonogenic common Flt3+M-CSFR+ plasmacytoid and conventional dendritic cell progenitors in mouse bone marrow. Nat Immunol (2007) 8(11):1207-16. doi:10.1038/ni1518

61. Lee J, Breton G, Oliveira TY, Zhou YJ, Aljoufi A, Puhr S, et al. Restricted dendritic cell and monocyte progenitors in human cord blood and bone marrow. J Exp Med (2015) 212(3):385-99. doi:10.1084/jem.20141442

62. Fogg DK, Sibon C, Miled C, Jung S, Aucouturier P, Littman DR, et al. A clonogenic bone marrow progenitor specific for macrophages and dendritic cells. Science (2006) 311(5757):83-7. doi:10.1126/science.1117729

63. Breton G, Lee J, Zhou YJ, Schreiber JJ, Keler T, Puhr S, et al. Circulating precursors of human CD1c+ and CD141+ dendritic cells. J Exp Med (2015) 212(3):401-13. doi:10.1084/jem.20141441

64. Liu K, Victora GD, Schwickert TA, Guermonprez P, Meredith MM, Yao K, et al. In vivo analysis of dendritic cell development and homeostasis. Science (2009) 324(5925):392-7. doi:10.1126/science.1170540

65. Schlenner SM, Madan V, Busch K, Tietz A, Laufle C, Costa C, et al. Fate mapping reveals separate origins of $\mathrm{T}$ cells and myeloid lineages in the thymus. Immunity (2010) 32(3):426-36. doi:10.1016/j.immuni.2010.03.005

66. Schraml BU, van Blijswijk J, Zelenay S, Whitney PG, Filby A, Acton SE, et al. Genetic tracing via DNGR-1 expression history defines dendritic cells as a hematopoietic lineage. Cell (2013) 154(4):843-58. doi:10.1016/j.cell.2013. 07.014

67. Naik SH, Perie L, Swart E, Gerlach C, van Rooij N, de Boer RJ, et al. Diverse and heritable lineage imprinting of early haematopoietic progenitors. Nature (2013) 496(7444):229-32. doi:10.1038/nature12013

68. Aliberti J, Schulz O, Pennington DJ, Tsujimura H, Reis e Sousa C, Ozato $\mathrm{K}$, et al. Essential role for ICSBP in the in vivo development of murine CD8alpha + dendritic cells. Blood (2003) 101(1):305-10. doi:10.1182/blood2002-04-1088

69. Tailor P, Tamura T, Morse HC III, Ozato K. The BXH2 mutation in IRF8 differentially impairs dendritic cell subset development in the mouse. Blood (2008) 111(4):1942-5. doi:10.1182/blood-2007-07-100750

70. Hambleton S, Salem S, Bustamante J, Bigley V, Boisson-Dupuis S, Azevedo J, et al. IRF8 mutations and human dendritic-cell immunodeficiency. $N$ Engl $J$ Med (2011) 365(2):127-38. doi:10.1056/NEJMoa1100066

71. Robbins SH, Walzer T, Dembele D, Thibault C, Defays A, Bessou G, et al. Novel insights into the relationships between dendritic cell subsets in human and mouse revealed by genome-wide expression profiling. Genome Biol (2008) 9(1):R17. doi:10.1186/gb-2008-9-1-r17

72. Cisse B, Caton ML, Lehner M, Maeda T, Scheu S, Locksley R, et al. Transcription factor E2-2 is an essential and specific regulator of plasmacytoid dendritic cell development. Cell (2008) 135(1):37-48. doi:10.1016/j. cell.2008.09.016

73. Schotte R, Nagasawa M, Weijer K, Spits H, Blom B. The ETS transcription factor Spi-B is required for human plasmacytoid dendritic cell development. J Exp Med (2004) 200(11):1503-9. doi:10.1084/jem.20041231

74. Sasaki I, Hoshino K, Sugiyama T, Yamazaki C, Yano T, Iizuka A, et al. Spi-B is critical for plasmacytoid dendritic cell function and development. Blood (2012) 120(24):4733-43. doi:10.1182/blood-2012-06-436527

75. Chicha L, Jarrossay D, Manz MG. Clonal type I interferon-producing and dendritic cell precursors are contained in both human lymphoid and myeloid progenitor populations. J Exp Med (2004) 200(11):1519-24. doi:10.1084/ jem.20040809

76. Karsunky H, Merad M, Mende I, Manz MG, Engleman EG, Weissman IL. Developmental origin of interferon-alpha-producing dendritic cells from hematopoietic precursors. Exp Hematol (2005) 33(2):173-81. doi:10.1016/j. exphem.2004.10.010

77. Onai N, Kurabayashi K, Hosoi-Amaike M, Toyama-Sorimachi N, Matsushima $\mathrm{K}$, Inaba $\mathrm{K}$, et al. A clonogenic progenitor with prominent plasmacytoid dendritic cell developmental potential. Immunity (2013) 38(5):943-57. doi:10.1016/j.immuni.2013.04.006

78. Mildner A, YonaS,JungS. Acloseencounterofthethirdkind:monocyte-derived cells. Adv Immunol (2013) 120:69-103. doi:10.1016/B978-0-12-417028-5. 00003-X 
79. Segura E, Amigorena S. Inflammatory dendritic cells in mice and humans. Trends Immunol (2013) 34(9):440-5. doi:10.1016/j.it.2013.06.001

80. Cook AD, Braine EL, Hamilton JA. Stimulus-dependent requirement for granulocyte-macrophage colony-stimulating factor in inflammation. J Immunol (2004) 173(7):4643-51. doi:10.4049/jimmunol.173.7.4643

81. Cheong C, Matos I, Choi JH, Dandamudi DB, Shrestha E, Longhi MP, et al. Microbial stimulation fully differentiates monocytes to DC-SIGN/ CD209(+) dendritic cells for immune T cell areas. Cell (2010) 143(3):416-29. doi:10.1016/j.cell.2010.09.039

82. Serbina NV, Salazar-Mather TP, Biron CA, Kuziel WA, Pamer EG. TNF/iNOS-producing dendritic cells mediate innate immune defense against bacterial infection. Immunity (2003) 19(1):59-70. doi:10.1016/ S1074-7613(03)00171-7

83. Greter M, Helft J, Chow A, Hashimoto D, Mortha A, Agudo-Cantero J, et al. GM-CSF controls nonlymphoid tissue dendritic cell homeostasis but is dispensable for the differentiation of inflammatory dendritic cells. Immunity (2012) 36(6):1031-46. doi:10.1016/j.immuni.2012.03.027

84. Inaba $\mathrm{K}$, Inaba $\mathrm{M}$, Deguchi $\mathrm{M}$, Hagi $\mathrm{K}$, Yasumizu $\mathrm{R}$, Ikehara $\mathrm{S}$, et al. Granulocytes, macrophages, and dendritic cells arise from a common major histocompatibility complex class II-negative progenitor in mouse bone marrow. Proc Natl Acad Sci U S A (1993) 90(7):3038-42. doi:10.1073/pnas.90.7.3038

85. Xu Y, Zhan Y, Lew AM, Naik SH, Kershaw MH. Differential development of murine dendritic cells by GM-CSF versus Flt3 ligand has implications for inflammation and trafficking. J Immunol (2007) 179(11):7577-84. doi:10.4049/jimmunol.179.11.7577

86. den Haan JM, Lehar SM, Bevan MJ. CD8(+) but not CD8(-) dendritic cells cross-prime cytotoxic T cells in vivo. J Exp Med (2000) 192(12):1685-96. doi:10.1084/jem.192.12.1685

87. Belz GT, Behrens GM, Smith CM, Miller JF, Jones C, Lejon K, et al. The CD8alpha(+) dendritic cell is responsible for inducing peripheral self-tolerance to tissue-associated antigens. J Exp Med (2002) 196(8):1099-104. doi:10.1084/jem.20020861

88. del Rio ML, Rodriguez-Barbosa JI, Kremmer E, Forster R. CD103- and $\mathrm{CD} 103+$ bronchial lymph node dendritic cells are specialized in presenting and cross-presenting innocuous antigen to $\mathrm{CD} 4+$ and $\mathrm{CD} 8+\mathrm{T}$ cells. J Immunol (2007) 178(11):6861-6. doi:10.4049/jimmunol.178.11.6861

89. Desch AN, Randolph GJ, Murphy K, Gautier EL, Kedl RM, Lahoud MH, et al. CD103+ pulmonary dendritic cells preferentially acquire and present apoptotic cell-associated antigen. J Exp Med (2011) 208(9):1789-97. doi:10.1084/ jem. 20110538

90. Allan RS, Smith CM, Belz GT, van Lint AL, Wakim LM, Heath WR, et al. Epidermal viral immunity induced by CD8alpha+ dendritic cells but not by Langerhans cells. Science (2003) 301(5641):1925-8. doi:10.1126/science. 1087576

91. Allan RS, Waithman J, Bedoui S, Jones CM, Villadangos JA, Zhan Y, et al. Migratory dendritic cells transfer antigen to a lymph node-resident dendritic cell population for efficient CTL priming. Immunity (2006) 25(1):153-62. doi:10.1016/j.immuni.2006.04.017

92. Segura E, Villadangos JA. Antigen presentation by dendritic cells in vivo. Curr Opin Immunol (2009) 21(1):105-10. doi:10.1016/j.coi.2009.03.011

93. Bedoui S, Whitney PG, Waithman J, Eidsmo L, Wakim L, Caminschi I, et al. Cross-presentation of viral and self antigens by skin-derived CD103+ dendritic cells. Nat Immunol (2009) 10(5):488-95. doi:10.1038/ni.1724

94. GeurtsvanKessel CH, Willart MA, van Rijt LS, Muskens F, Kool M, Baas $\mathrm{C}$, et al. Clearance of influenza virus from the lung depends on migratory langerin+CD11b- but not plasmacytoid dendritic cells. J Exp Med (2008) 205(7):1621-34. doi:10.1084/jem.20071365

95. Lundie RJ, de Koning-Ward TF, Davey GM, Nie CQ, Hansen DS, Lau LS, et al. Blood-stage Plasmodium infection induces CD8+ T lymphocytes to parasite-expressed antigens, largely regulated by CD8alpha+ dendritic cells. Proc Natl Acad Sci U S A (2008) 105(38):14509-14. doi:10.1073/pnas.0806727105

96. Guermonprez P, Helft J, Claser C, Deroubaix S, Karanje H, Gazumyan A, et al. Inflammatory Flt3l is essential to mobilize dendritic cells and for $\mathrm{T}$ cell responses during Plasmodium infection. Nat Med (2013) 19(6):730-8. doi:10.1038/nm.3197

97. Piva L, Tetlak P, Claser C, Karjalainen K, Renia L, Ruedl C. Cutting edge: Clec9A+ dendritic cells mediate the development of experimental cerebral malaria. J Immunol (2012) 189(3):1128-32. doi:10.4049/jimmunol.1201171
98. Lau LS, Fernandez Ruiz D, Davey GM, de Koning-Ward TF, Papenfuss AT, Carbone FR, et al. Blood-stage Plasmodium berghei infection generates a potent, specific CD8+ T-cell response despite residence largely in cells lacking MHC I processing machinery. J Infect Dis (2011) 204(12):1989-96. doi:10.1093/infdis/jir656

99. Segura E, Albiston AL, Wicks IP, Chai SY, Villadangos JA. Different cross-presentation pathways in steady-state and inflammatory dendritic cells. Proc Natl Acad Sci U S A (2009) 106(48):20377-81. doi:10.1073/ pnas.0910295106

100. Le Borgne M, Etchart N, Goubier A, Lira SA, Sirard JC, van Rooijen N, et al. Dendritic cells rapidly recruited into epithelial tissues via CCR6/CCL20 are responsible for CD8+ T cell crosspriming in vivo. Immunity (2006) 24(2):191-201. doi:10.1016/j.immuni.2006.01.005

101. Wakim LM, Waithman J, van Rooijen N, Heath WR, Carbone FR. Dendritic cell-induced memory $\mathrm{T}$ cell activation in nonlymphoid tissues. Science (2008) 319(5860):198-202. doi:10.1126/science.1151869

102. Gehring AJ, Haniffa M, Kennedy PT, Ho ZZ, Boni C, Shin A, et al. Mobilizing monocytes to cross-present circulating viral antigen in chronic infection. $J$ Clin Invest (2013) 123(9):3766-76. doi:10.1172/JCI66043

103. Mouries J, Moron G, Schlecht G, Escriou N, Dadaglio G, Leclerc C. Plasmacytoid dendritic cells efficiently cross-prime naive $\mathrm{T}$ cells in vivo after TLR activation. Blood (2008) 112(9):3713-22. doi:10.1182/ blood-2008-03-146290

104. Sapoznikov A, Fischer JA, Zaft T, Krauthgamer R, Dzionek A, Jung S. Organ-dependent in vivo priming of naive CD4+, but not CD8+, T cells by plasmacytoid dendritic cells. J Exp Med (2007) 204(8):1923-33. doi:10.1084/ jem. 20062373

105. Swiecki M, Gilfillan S, Vermi W, Wang Y, Colonna M. Plasmacytoid dendritic cell ablation impacts early interferon responses and antiviral NK and CD8(+) T cell accrual. Immunity (2010) 33(6):955-66. doi:10.1016/j. immuni.2010.11.020

106. Cervantes-Barragan L, Lewis KL, Firner S, Thiel V, Hugues S, Reith W, et al. Plasmacytoid dendritic cells control T-cell response to chronic viral infection. Proc Natl Acad Sci U S A (2012) 109(8):3012-7. doi:10.1073/pnas.11173 59109

107. Segura E, Valladeau-Guilemond J, Donnadieu MH, Sastre-Garau X, Soumelis $\mathrm{V}$, Amigorena S. Characterization of resident and migratory dendritic cells in human lymph nodes. J Exp Med (2012) 209(4):653-60. doi:10.1084/ jem.20111457

108. Segura E, Durand M, Amigorena S. Similar antigen cross-presentation capacity and phagocytic functions in all freshly isolated human lymphoid organ-resident dendritic cells. JExp Med (2013) 210(5):1035-47. doi:10.1084/ jem. 20121103

109. Tel J, Sittig SP, Blom RA, Cruz LJ, Schreibelt G, Figdor CG, et al. Targeting uptake receptors on human plasmacytoid dendritic cells triggers antigen cross-presentation and robust type I IFN secretion. JImmunol (2013) 191(10):5005-12. doi:10.4049/jimmunol.1300787

110. Haniffa M, Shin A, Bigley V, McGovern N, Teo P, See P, et al. Human tissues contain CD141hi cross-presenting dendritic cells with functional homology to mouse CD103+ nonlymphoid dendritic cells. Immunity (2012) 37(1):60-73. doi:10.1016/j.immuni.2012.04.012

111. Hoeffel G, Ripoche AC, Matheoud D, Nascimbeni M, Escriou N, Lebon P, et al. Antigen crosspresentation by human plasmacytoid dendritic cells. Immunity (2007) 27(3):481-92. doi:10.1016/j.immuni.2007.07.021

112. Balan S, Ollion V, Colletti N, Chelbi R, Montanana-Sanchis F, Liu H, et al. Human XCR1+ dendritic cells derived in vitro from CD34+ progenitors closely resemble blood dendritic cells, including their adjuvant responsiveness, contrary to monocyte-derived dendritic cells. J Immunol (2014) 193(4):1622-35. doi:10.4049/jimmunol.1401243

113. Proietto AI, Mittag D, Roberts AW, Sprigg N, Wu L. The equivalents of human blood and spleen dendritic cell subtypes can be generated in vitro from human $\mathrm{CD} 34(+)$ stem cells in the presence of fms-like tyrosine kinase 3 ligand and thrombopoietin. Cell Mol Immunol (2012) 9(6):446-54. doi:10.1038/ cmi.2012.48

114. Klechevsky E, Morita R, Liu M, Cao Y, Coquery S, Thompson-Snipes L, et al. Functional specializations of human epidermal Langerhans cells and CD14+ dermal dendritic cells. Immunity (2008) 29(3):497-510. doi:10.1016/j. immuni.2008.07.013 
115. Polak ME, Newell L, Taraban VY, Pickard C, Healy E, Friedmann PS, et al. CD70-CD27 interaction augments CD8+ T-cell activation by human epidermal Langerhans cells. J Invest Dermatol (2012) 132(6):1636-44. doi:10.1038/ jid.2012.26

116. Poon IK, Lucas CD, Rossi AG, Ravichandran KS. Apoptotic cell clearance: basic biology and therapeutic potential. Nat Rev Immunol (2014) 14(3):16680. doi:10.1038/nri3607

117. Miyanishi M, Tada K, Koike M, Uchiyama Y, Kitamura T, Nagata S. Identification of Tim4 as a phosphatidylserine receptor. Nature (2007) 450(7168):435-9. doi:10.1038/nature06307

118. Toda S, Hanayama R, Nagata S. Two-step engulfment of apoptotic cells. Mol Cell Biol (2012) 32(1):118-25. doi:10.1128/MCB.05993-11

119. Albert ML, Pearce SF, Francisco LM, Sauter B, Roy P, Silverstein RL, et al. Immature dendritic cells phagocytose apoptotic cells via alphavbeta5 and CD36, and cross-present antigens to cytotoxic T lymphocytes. J Exp Med (1998) 188(7):1359-68. doi:10.1084/jem.188.7.1359

120. Belz GT, Vremec D, Febbraio M, Corcoran L, Shortman K, Carbone FR, et al. CD36 is differentially expressed by CD8+ splenic dendritic cells but is not required for cross-presentation in vivo. J Immunol (2002) 168(12):6066-70. doi:10.4049/jimmunol.168.12.6066

121. Schulz O, Pennington DJ, Hodivala-Dilke K, Febbraio M, Reis e Sousa C. CD36 or alphavbeta3 and alphavbeta5 integrins are not essential for MHC class I cross-presentation of cell-associated antigen by CD8 alpha+ murine dendritic cells. JImmunol (2002) 168(12):6057-65. doi:10.4049/ jimmunol.168.12.6057

122. Subramanian M, Hayes CD, Thome JJ, Thorp E, Matsushima GK, Herz J, et al. An AXL/LRP-1/RANBP9 complex mediates DC efferocytosis and antigen cross-presentation in vivo. J Clin Invest (2014) 124(3):1296-308. doi:10.1172/ JCI72051

123. Bondanza A, Zimmermann VS, Rovere-Querini P, Turnay J, Dumitriu IE, Stach CM, et al. Inhibition of phosphatidylserine recognition heightens the immunogenicity of irradiated lymphoma cells in vivo. J Exp Med (2004) 200(9):1157-65. doi:10.1084/jem.20040327

124. Shrimpton RE, Butler M, Morel AS, Eren E, Hue SS, Ritter MA. CD205 (DEC-205): a recognition receptor for apoptotic and necrotic self. Mol Immunol (2009) 46(6):1229-39. doi:10.1016/j.molimm.2008.11.016

125. Sancho D, Joffre OP, Keller AM, Rogers NC, Martinez D, Hernanz-Falcon $\mathrm{P}$, et al. Identification of a dendritic cell receptor that couples sensing of necrosis to immunity. Nature (2009) 458(7240):899-903. doi:10.1038/ nature 07750

126. Ahrens S, Zelenay S, Sancho D, Hanc P, Kjaer S, Feest C, et al. F-actin is an evolutionarily conserved damage-associated molecular pattern recognized by DNGR-1, a receptor for dead cells. Immunity (2012) 36(4):635-45. doi:10.1016/j.immuni.2012.03.008

127. Zhang JG, Czabotar PE, Policheni AN, Caminschi I, Wan SS, Kitsoulis S, et al. The dendritic cell receptor Clec9A binds damaged cells via exposed actin filaments. Immunity (2012) 36(4):646-57. doi:10.1016/j.immuni.2012.03.009

128. Hanc P, Fujii T, Iborra S, Yamada Y, Huotari J, Schulz O, et al. Structure of the complex of F-actin and DNGR-1, a C-type lectin receptor involved in dendritic cell cross-presentation of dead cell-associated antigens. Immunity (2015) 42(5):839-49. doi:10.1016/j.immuni.2015.04.009

129. Huysamen C, Willment JA, Dennehy KM, Brown GD. CLEC9A is a novel activation C-type lectin-like receptor expressed on BDCA3+ dendritic cells and a subset of monocytes. J Biol Chem (2008) 283(24):16693-701. doi:10.1074/jbc.M709923200

130. Sancho D, Mourao-Sa D, Joffre OP, Schulz O, Rogers NC, Pennington DJ, et al. Tumor therapy in mice via antigen targeting to a novel, DC-restricted C-type lectin. J Clin Invest (2008) 118(6):2098-110. doi:10.1172/JCI34584

131. Nakayama M, Akiba H, Takeda K, Kojima Y, Hashiguchi M, Azuma M, et al. Tim-3 mediates phagocytosis of apoptotic cells and cross-presentation. Blood (2009) 113(16):3821-30. doi:10.1182/blood-2008-10-185884

132. Chiba S, Baghdadi M, Akiba H, Yoshiyama H, Kinoshita I, Dosaka-Akita H, et al. Tumor-infiltrating DCs suppress nucleic acid-mediated innate immune responses through interactions between the receptor TIM-3 and the alarmin HMGB1. Nat Immunol (2012) 13(9):832-42. doi:10.1038/ni.2376

133. Ramirez-Ortiz ZG, Pendergraft WF III, Prasad A, Byrne MH, Iram T, Blanchette CJ, et al. The scavenger receptor SCARF1 mediates the clearance of apoptotic cells and prevents autoimmunity. Nat Immunol (2013) 14(9):917-26. doi:10.1038/ni.2670
134. Schnorrer P, Behrens GM, Wilson NS, Pooley JL, Smith CM, El-Sukkari D, et al. The dominant role of CD8+ dendritic cells in cross-presentation is not dictated by antigen capture. Proc Natl Acad Sci U S A (2006) 103(28):1072934. doi:10.1073/pnas.0601956103

135. Giodini A, Rahner C, Cresswell P. Receptor-mediated phagocytosis elicits cross-presentation in nonprofessional antigen-presenting cells. Proc Natl Acad Sci U S A (2009) 106(9):3324-9. doi:10.1073/pnas.0813305106

136. Schulz O, Reis e Sousa C. Cross-presentation of cell-associated antigens by CD8alpha+dendriticcellsisattributable to their ability to internalize dead cells. Immunology (2002) 107(2):183-9. doi:10.1046/j.1365-2567.2002.01513.x

137. Backer R, van Leeuwen F, Kraal G, den Haan JM. CD8- dendritic cells preferentially cross-present Saccharomyces cerevisiae antigens. Eur J Immunol (2008) 38(2):370-80. doi:10.1002/eji.200737647

138. Igyarto BZ, Haley K, Ortner D, Bobr A, Gerami-Nejad M, Edelson BT, et al. Skin-resident murine dendritic cell subsets promote distinct and opposing antigen-specific T helper cell responses. Immunity (2011) 35(2):260-72. doi:10.1016/j.immuni.2011.06.005

139. Kamphorst AO, Guermonprez P, Dudziak D, Nussenzweig MC. Route of antigen uptake differentially impacts presentation by dendritic cells and activated monocytes. J Immunol (2010) 185(6):3426-35. doi:10.4049/jimmunol. 1001205

140. Dudziak D, Kamphorst AO, Heidkamp GF, Buchholz VR, Trumpfheller C, Yamazaki S, et al. Differential antigen processing by dendritic cell subsets in vivo. Science (2007) 315(5808):107-11. doi:10.1126/science.1136080

141. Chatterjee B, Smed-Sorensen A, Cohn L, Chalouni C, Vandlen R, Lee BC, et al. Internalization and endosomal degradation of receptor-bound antigens regulate the efficiency of cross presentation by human dendritic cells. Blood (2012) 120(10):2011-20. doi:10.1182/blood-2012-01-402370

142. Cohn L, Chatterjee B, Esselborn F, Smed-Sorensen A, Nakamura N, Chalouni $\mathrm{C}$, et al. Antigen delivery to early endosomes eliminates the superiority of human blood BDCA3+ dendritic cells at cross presentation. J Exp Med (2013) 210(5):1049-63. doi:10.1084/jem.20121251

143. Cohn L, Delamarre L. Dendritic cell-targeted vaccines. Front Immunol (2014) 5:255. doi:10.3389/fimmu.2014.00255

144. Regnault A, Lankar D, Lacabanne V, Rodriguez A, Thery C, Rescigno M, et al. Fcgamma receptor-mediated induction of dendritic cell maturation and major histocompatibility complex class I-restricted antigen presentation after immunecomplexinternalization.JExpMed(1999) 189(2):371-80.doi:10.1084/ jem.189.2.371

145. den Haan JM, Bevan MJ. Constitutive versus activation-dependent cross-presentation of immune complexes by $\mathrm{CD} 8(+)$ and $\mathrm{CD} 8(-)$ dendritic cells in vivo. J Exp Med (2002) 196(6):817-27. doi:10.1084/ jem. 20020295

146. Dhodapkar KM, Krasovsky J, Williamson B, Dhodapkar MV. Antitumor monoclonal antibodies enhance cross-presentation ofcCellular antigens and the generation of myeloma-specific killer T cells by dendritic cells. J Exp Med (2002) 195(1):125-33. doi:10.1084/jem.20011097

147. Harbers SO, Crocker A, Catalano G, D’Agati V, Jung S, Desai DD, et al. Antibody-enhanced cross-presentation of self antigen breaks T cell tolerance. J Clin Invest (2007) 117(5):1361-9. doi:10.1172/JCI29470

148. Blum JS, Wearsch PA, Cresswell P. Pathways of antigen processing. Annu Rev Immunol(2013)31:443-73. doi:10.1146/annurev-immunol-032712-095910

149. Kovacsovics-Bankowski M, Rock KL. A phagosome-to-cytosol pathway for exogenous antigens presented on MHC class I molecules. Science (1995) 267(5195):243-6. doi:10.1126/science.7809629

150. Huang AY, Bruce AT, Pardoll DM, Levitsky HI. In vivo cross-priming of MHC class I-restricted antigens requires the TAP transporter. Immunity (1996) 4(4):349-55. doi:10.1016/S1074-7613(00)80248-4

151. Fonteneau JF, Kavanagh DG, Lirvall M, Sanders C, Cover TL, Bhardwaj $\mathrm{N}$, et al. Characterization of the MHC class I cross-presentation pathway for cell-associated antigens by human dendritic cells. Blood (2003) 102(13):4448-55. doi:10.1182/blood-2003-06-1801

152. Van Kaer L, Ashton-Rickardt PG, Ploegh HL, Tonegawa S. TAP1 mutant mice are deficient in antigen presentation, surface class I molecules, and CD4-8+ T cells. Cell (1992) 71(7):1205-14. doi:10.1016/S0092-8674(05)80068-6

153. Chefalo PJ, Grandea AG III, Van Kaer L, Harding CV. Tapasin-/- and TAP1-/macrophages are deficient in vacuolar alternate class I MHC (MHC-I) processing due to decreased MHC-I stability at phagolysosomal pH. J Immunol (2003) 170(12):5825-33. doi:10.4049/jimmunol.170.1.643 
154. Merzougui N, Kratzer R, Saveanu L, van Endert P. A proteasome-dependent, TAP-independent pathway for cross-presentation of phagocytosed antigen. EMBO Rep (2011) 12(12):1257-64. doi:10.1038/embor.2011.203

155. Pfeifer JD, Wick MJ, Roberts RL, Findlay K, Normark SJ, Harding CV. Phagocytic processing of bacterial antigens for class I MHC presentation to T cells. Nature (1993) 361(6410):359-62. doi:10.1038/361359a0

156. Shen L, Sigal LJ, Boes M, Rock KL. Important role of cathepsin S in generating peptides for TAP-independent MHC class I crosspresentation in vivo. Immunity (2004) 21(2):155-65. doi:10.1016/j.immuni.2004.07.004

157. Lennon-Dumenil AM, Bakker AH, Maehr R, Fiebiger E, Overkleeft HS, Rosemblatt M, et al. Analysis of protease activity in live antigen-presenting cells shows regulation of the phagosomal proteolytic contents during dendritic cell activation. J Exp Med (2002) 196(4):529-40. doi:10.1084/jem.20020327

158. Delamarre L, Pack M, Chang H, Mellman I, Trombetta ES. Differential lysosomal proteolysis in antigen-presenting cells determines antigen fate. Science (2005) 307(5715):1630-4. doi:10.1126/science.1108003

159. McCurley N, Mellman I. Monocyte-derived dendritic cells exhibit increased levels of lysosomal proteolysis as compared to other human dendritic cell populations. PLoS One (2010) 5(8):e11949. doi:10.1371/journal. pone.0011949

160. Accapezzato D, Visco V, Francavilla V, Molette C, Donato T, Paroli M, et al. Chloroquine enhances human $\mathrm{CD} 8+\mathrm{T}$ cell responses against soluble antigens in vivo. J Exp Med (2005) 202(6):817-28. doi:10.1084/jem.20051106

161. Belizaire R, Unanue ER. Targeting proteins to distinct subcellular compartments reveals unique requirements for MHC class I and II presentation. Proc Natl Acad Sci U S A (2009) 106(41):17463-8. doi:10.1073/pnas.0908583106

162. Trombetta ES, Ebersold M, Garrett W, Pypaert M, Mellman I. Activation of lysosomal function during dendritic cell maturation. Science (2003) 299(5611):1400-3. doi:10.1126/science.1080106

163. Liberman R, Bond S, Shainheit MG, Stadecker MJ, Forgac M. Regulated assembly of vacuolar ATPase is increased during cluster disruption-induced maturation of dendritic cells through a phosphatidylinositol 3-kinase/mTOR-dependent pathway. J Biol Chem (2014) 289(3):1355-63. doi:10.1074/jbc.M113.524561

164. Savina A, Jancic C, Hugues S, Guermonprez P, Vargas P, Moura IC, et al. NOX2 controls phagosomal $\mathrm{pH}$ to regulate antigen processing during crosspresentation by dendritic cells. Cell (2006) 126(1):205-18. doi:10.1016/j. cell.2006.05.035

165. Mantegazza AR, Savina A, Vermeulen M, Perez L, Geffner J, Hermine O, et al. NADPH oxidase controls phagosomal $\mathrm{pH}$ and antigen cross-presentation in human dendritic cells. Blood (2008) 112(12):4712-22. doi:10.1182/ blood-2008-01-134791

166. Savina A, Peres A, Cebrian I, Carmo N, Moita C, Hacohen N, et al. The small GTPase Rac2 controls phagosomal alkalinization and antigen crosspresentation selectively in CD8(+) dendritic cells. Immunity (2009) 30(4):544-55. doi:10.1016/j.immuni.2009.01.013

167. Bougneres L, Helft J, Tiwari S, Vargas P, Chang BH, Chan L, et al. A role for lipid bodies in the cross-presentation of phagocytosed antigens by MHC class I in dendritic cells. Immunity (2009) 31(2):232-44. doi:10.1016/j. immuni.2009.06.022

168. Saka HA, Valdivia R. Emerging roles for lipid droplets in immunity and hostpathogen interactions. Annu Rev Cell Dev Biol (2012) 28:411-37. doi:10.1146/ annurev-cellbio-092910-153958

169. Shmelzer Z, Haddad N, Admon E, Pessach I, Leto TL, Eitan-Hazan Z, et al. Unique targeting of cytosolic phospholipase A2 to plasma membranes mediated by the NADPH oxidase in phagocytes. J Cell Biol (2003) 162(4):683-92. doi: $10.1083 / j$ cb. 200211056

170. van Manen HJ, Kraan YM, Roos D, Otto C. Single-cell Raman and fluorescence microscopy reveal the association of lipid bodies with phagosomes in leukocytes. Proc Natl Acad Sci U S A (2005) 102(29):10159-64. doi:10.1073/ pnas.0502746102

171. Dana R, Leto TL, Malech HL, Levy R. Essential requirement of cytosolic phospholipase A2 for activation of the phagocyte NADPH oxidase. J Biol Chem (1998) 273(1):441-5. doi:10.1074/jbc.273.1.441

172. Doussiere J, Bouzidi F, Poinas A, Gaillard J, Vignais PV. Kinetic study of the activation of the neutrophil NADPH oxidase by arachidonic acid. Antagonistic effects of arachidonic acid and phenylarsine oxide. Biochemistry (1999) 38(49):16394-406. doi:10.1021/bi9823481
173. Lutz MB, Rovere P, Kleijmeer MJ, Rescigno M, Assmann CU, Oorschot VM, et al. Intracellular routes and selective retention of antigens in mildly acidic cathepsin D/lysosome-associated membrane protein-1/MHC class II-positive vesicles in immature dendritic cells. J Immunol (1997) 159(8):3707-16.

174. van Montfoort N, Camps MG, Khan S, Filippov DV, Weterings JJ, Griffith $\mathrm{JM}$, et al. Antigen storage compartments in mature dendritic cells facilitate prolonged cytotoxic T lymphocyte cross-priming capacity. Proc Natl Acad Sci U S A (2009) 106(16):6730-5. doi:10.1073/pnas.0900969106

175. Burgdorf S, Kautz A, Bohnert V, Knolle PA, Kurts C. Distinct pathways of antigen uptake and intracellular routing in CD4 and CD8 T cell activation. Science (2007) 316(5824):612-6. doi:10.1126/science.1137971

176. Burgdorf S, Scholz C, Kautz A, Tampe R, Kurts C. Spatial and mechanistic separation of cross-presentation and endogenous antigen presentation. Nat Immunol (2008) 9(5):558-66. doi:10.1038/ni.1601

177. Burgdorf S, Schuette V, Semmling V, Hochheiser K, Lukacs-Kornek V, Knolle $\mathrm{PA}$, et al. Steady-state cross-presentation of OVA is mannose receptor-dependent but inhibitable by collagen fragments. Proc Natl Acad Sci U S A (2010) 107(13):E48-9. doi:10.1073/pnas.1000598107

178. Saveanu L, Carroll O, Weimershaus M, Guermonprez P, Firat E, Lindo $\mathrm{V}$, et al. IRAP identifies an endosomal compartment required for MHC class I cross-presentation. Science (2009) 325(5937):213-7. doi:10.1126/ science. 1172845

179. Weimershaus M, Maschalidi S, Sepulveda F, Manoury B, van Endert P, Saveanu L. Conventional dendritic cells require IRAP-Rab14 endosomes for efficient cross-presentation. J Immunol (2012) 188(4):1840-6. doi:10.4049/ jimmunol.1101504

180. Weimershaus M, Evnouchidou I, Saveanu L, van Endert P. Peptidases trimming MHC class I ligands. Curr Opin Immunol (2013) 25(1):90-6. doi:10.1016/j.coi.2012.10.001

181. Iborra S, Izquierdo HM, Martinez-Lopez M, Blanco-Menendez N, Reis e Sousa C, Sancho D. The DC receptor DNGR-1 mediates cross-priming of CTLs during vaccinia virus infection in mice. J Clin Invest (2012) 122(5):1628-43. doi:10.1172/JCI60660

182. Zelenay S, Keller AM, Whitney PG, Schraml BU, Deddouche S, Rogers NC, et al. The dendritic cell receptor DNGR-1 controls endocytic handling of necrotic cell antigens to favor cross-priming of CTLs in virus-infected mice. J Clin Invest (2012) 122(5):1615-27. doi:10.1172/JCI60644

183. Reboulet RA, Hennies CM, Garcia Z, Nierkens S, Janssen EM. Prolonged antigen storage endows merocytic dendritic cells with enhanced capacity to prime anti-tumor responses in tumor-bearing mice. J Immunol (2010) 185(6):3337-47. doi:10.4049/jimmunol.1001619

184. Thacker RI, Janssen EM. Cross-presentation of cell-associated antigens by mouse splenic dendritic cell populations. Front Immunol (2012) 3:41. doi:10.3389/fimmu.2012.00041

185. Norbury CC, Hewlett LJ, Prescott AR, Shastri N, Watts C. Class I MHC presentation of exogenous soluble antigen via macropinocytosis in bone marrow macrophages. Immunity (1995) 3(6):783-91. doi:10.1016/1074-7613(95) 90067-5

186. Brossart P, Bevan MJ. Presentation of exogenous protein antigens on major histocompatibility complex class I molecules by dendritic cells: pathway of presentation and regulation by cytokines. Blood (1997) 90(4):1594-9.

187. Norbury CC, Chambers BJ, Prescott AR, Ljunggren HG, Watts C. Constitutive macropinocytosis allows TAP-dependent major histocompatibility complex class I presentation of exogenous soluble antigen by bone marrow-derived dendritic cells. EurJ Immunol (1997) 27(1):280-8. doi:10.1002/eji.1830270141

188. Rodriguez A, Regnault A, Kleijmeer M, Ricciardi-Castagnoli P, Amigorena S. Selective transport of internalized antigens to the cytosol for MHC class I presentation in dendritic cells. Nat Cell Biol (1999) 1(6):362-8. doi:10.1038/14058

189. Hotta C, Fujimaki H, Yoshinari M, Nakazawa M, Minami M. The delivery of an antigen from the endocytic compartment into the cytosol for cross-presentation is restricted to early immature dendritic cells. Immunology (2006) 117(1):97-107. doi:10.1111/j.1365-2567.2005.02270.x

190. Palmowski MJ, Gileadi U, Salio M, Gallimore A, Millrain M, James E, et al. Role of immunoproteasomes in cross-presentation. J Immunol (2006) 177(2):983-90. doi:10.4049/jimmunol.177.2.983

191. Lin ML, Zhan Y, Proietto AI, Prato S, Wu L, Heath WR, et al. Selective suicide of cross-presenting CD8+ dendritic cells by cytochrome $\mathrm{c}$ injection shows 
functional heterogeneity within this subset. Proc Natl Acad Sci U S A (2008) 105(8):3029-34. doi:10.1073/pnas.0712394105

192. Moore MW, Carbone FR, Bevan MJ. Introduction of soluble protein into the class I pathway of antigen processing and presentation. Cell (1988) 54(6):777-85. doi:10.1016/S0092-8674(88)91043-4

193. Boya P, Kroemer G. Lysosomal membrane permeabilization in cell death. Oncogene (2008) 27(50):6434-51. doi:10.1038/onc.2008.310

194. Wiertz EJ, Tortorella D, Bogyo M, Yu J, Mothes W, Jones TR, et al. Sec61mediated transfer of a membrane protein from the endoplasmic reticulum to the proteasome for destruction. Nature (1996) 384(6608):432-8. doi:10.1038/ 384432a0

195. Schafer A, Wolf DH. Sec61p is part of the endoplasmic reticulum-associated degradation machinery. EMBO J (2009) 28(19):2874-84. doi:10.1038/emboj. 2009.231

196. Gagnon E, Duclos S, Rondeau C, Chevet E, Cameron PH, Steele-Mortimer $\mathrm{O}$, et al. Endoplasmic reticulum-mediated phagocytosis is a mechanism of entry into macrophages. Cell (2002) 110(1):119-31. doi:10.1016/S0092-8674 (02)00797-3

197. Guermonprez P, Saveanu L, Kleijmeer M, Davoust J, Van Endert P, Amigorena S. ER-phagosome fusion defines an MHC class I cross-presentation compartment in dendritic cells. Nature (2003) 425(6956):397-402. doi:10.1038/nature01911

198. Houde M, Bertholet S, Gagnon E, Brunet S, Goyette G, Laplante A, et al. Phagosomes are competent organelles for antigen cross-presentation. Nature (2003) 425(6956):402-6. doi:10.1038/nature01912

199. Cebrian I, Visentin G, Blanchard N, Jouve M, Bobard A, Moita C, et al. $\mathrm{Sec} 2 \mathrm{~b}$ regulates phagosomal maturation and antigen crosspresentation by dendritic cells. Cell (2011) 147(6):1355-68. doi:10.1016/j.cell.2011.11.021

200. Koopmann JO, Albring J, Huter E, Bulbuc N, Spee P, Neefjes J, et al. Export of antigenic peptides from the endoplasmic reticulum intersects with retrograde protein translocation through the Sec61p channel. Immunity (2000) 13(1):117-27. doi:10.1016/S1074-7613(00)00013-3

201. Hirasawa T, Ohsawa K, Imai Y, Ondo Y, Akazawa C, Uchino S, et al. Visualization of microglia in living tissues using Ibal-EGFP transgenic mice. J Neurosci Res (2005) 81(3):357-62. doi:10.1002/jnr.20480

202. Zehner M, Marschall AL, Bos E, Schloetel JG, Kreer C, Fehrenschild D, et al. The translocon protein sec61 mediates antigen transport from endosomes in the cytosol for cross-presentation to CD8(+) T cells. Immunity (2015) 42(5):850-63. doi:10.1016/j.immuni.2015.04.008

203. Menager J, Ebstein F, Oger R, Hulin P, Nedellec S, Duverger E, et al. Crosspresentation of synthetic long peptides by human dendritic cells: a process dependent on ERAD component p97/VCP but Not sec61 and/or Derlin-1. PLoS One (2014) 9(2):e89897. doi:10.1371/journal.pone.0089897

204. Smith MH, Ploegh HL, Weissman JS. Road to ruin: targeting proteins for degradation in the endoplasmic reticulum. Science (2011) 334(6059):1086-90. doi:10.1126/science.1209235

205. Ackerman AL, Giodini A, Cresswell P. A role for the endoplasmic reticulum protein retrotranslocation machinery during crosspresentation by dendritic cells. Immunity (2006) 25(4):607-17. doi:10.1016/j. immuni.2006.08.017

206. Imai T, Kato Y, Kajiwara C, Mizukami S, Ishige I, Ichiyanagi T, et al. Heat shock protein 90 (HSP90) contributes to cytosolic translocation of extracellular antigen for cross-presentation by dendritic cells. Proc Natl Acad Sci U S A (2011) 108(39):16363-8. doi:10.1073/pnas.1108372108

207. Giodini A, Cresswell P. Hsp90-mediated cytosolic refolding of exogenous proteins internalized by dendritic cells. EMBO J (2008) 27(1):201-11. doi:10.1038/sj.emboj.7601941

208. Ichiyanagi T, Imai T, Kajiwara C, Mizukami S, Nakai A, Nakayama T, et al. Essential role of endogenous heat shock protein 90 of dendritic cells in antigen cross-presentation. J Immunol (2010) 185(5):2693-700. doi:10.4049/ jimmunol.1000821

209. Singh R, Cresswell P. Defective cross-presentation of viral antigens in GILTfree mice. Science (2010) 328(5984):1394-8. doi:10.1126/science.1189176
210. Ackerman AL, Kyritsis C, Tampe R, Cresswell P. Access of soluble antigens to the endoplasmic reticulum can explain cross-presentation by dendritic cells. Nat Immunol (2005) 6(1):107-13. doi:10.1038/ni1147

211. Donaldson JG, Williams DB. Intracellular assembly and trafficking of MHC class I molecules. Traffic (2009) 10(12):1745-52. doi:10.1111/j.1600-0854. 2009.00979.x

212. Lizee G, Basha G, Tiong J, Julien JP, Tian M, Biron KE, et al. Control of dendritic cell cross-presentation by the major histocompatibility complex class I cytoplasmic domain. Nat Immunol (2003) 4(11):1065-73. doi:10.1038/ ni989

213. Basha G, Omilusik K, Chavez-Steenbock A, Reinicke AT, Lack N, Choi KB, et al. A CD74-dependent MHC class I endolysosomal cross-presentation pathway. Nat Immunol (2012) 13(3):237-45. doi:10.1038/ni.2225

214. Nair-Gupta P, Baccarini A, Tung N, Seyffer F, Florey O, Huang Y, et al. TLR signals induce phagosomal MHC-I delivery from the endosomal recycling compartment to allow cross-presentation. Cell (2014) 158(3):506-21. doi:10.1016/j.cell.2014.04.054

215. Janssen E, Tabeta K, Barnes MJ, Rutschmann S, McBride S, Bahjat KS, et al. Efficient $\mathrm{T}$ cell activation via a toll-interleukin 1 receptor-independent pathway. Immunity (2006) 24(6):787-99. doi:10.1016/j.immuni.2006.03.024

216. Schulz O, Diebold SS, Chen M, Naslund TI, Nolte MA, Alexopoulou L, et al. Toll-like receptor 3 promotes cross-priming to virus-infected cells. Nature (2005) 433(7028):887-92. doi:10.1038/nature03326

217. Desch AN, Gibbings SL, Clambey ET, Janssen WJ, Slansky JE, Kedl RM, et al. Dendritic cell subsets require cis-activation for cytotoxic CD8 T-cell induction. Nat Commun (2014) 5:4674. doi:10.1038/ncomms5674

218. Datta SK, Redecke V, Prilliman KR, Takabayashi K, Corr M, Tallant T, et al. A subset of toll-like receptor ligands induces cross-presentation by bone marrow-derived dendritic cells. J Immunol (2003) 170(8):4102-10. doi:10.4049/ jimmunol.170.8.4102

219. Gil-Torregrosa BC, Lennon-Dumenil AM, Kessler B, Guermonprez P, Ploegh HL, Fruci D, et al. Control of cross-presentation during dendritic cell maturation. Eur JImmunol (2004) 34(2):398-407. doi:10.1002/ eji.200324508

220. Tabeta K, Hoebe K, Janssen EM, Du X, Georgel P, Crozat K, et al. The Unc93b1 mutation $3 \mathrm{~d}$ disrupts exogenous antigen presentation and signaling via toll-like receptors 3, 7 and 9. Nat Immunol (2006) 7(2):156-64. doi:10.1038/ nrm1901

221. Brinkmann MM, Spooner E, Hoebe K, Beutler B, Ploegh HL, Kim YM. The interaction between the ER membrane protein UNC93B and TLR3, 7, and 9 is crucial for TLR signaling. J Cell Biol (2007) 177(2):265-75. doi:10.1083/ jcb.200612056

222. Kim YM, Brinkmann MM, Paquet ME, Ploegh HL. UNC93B1 delivers nucleotide-sensing toll-like receptors to endolysosomes. Nature (2008) 452(7184):234-8. doi:10.1038/nature06726

223. Deguine J, Lee BL, Newman ZR, Barton GM. No antigen-presentation defect in Unc93b1(3d/3d) (3d) mice. Nat Immunol (2013) 14(11):1101-2. doi:10.1038/ni.2733

Conflict of Interest Statement: The authors declare that the research was conducted in the absence of any commercial or financial relationships that could be construed as a potential conflict of interest. The Review Editor Bénédicte Manoury declares that, despite having collaborated with Loredana Saveanu within the past 2 years, the review process was handled objectively.

Copyright $\odot 2015$ Gutiérrez-Martínez, Planès, Anselmi, Reynolds, Menezes, Adiko, Saveanu and Guermonprez. This is an open-access article distributed under the terms of the Creative Commons Attribution License (CC BY). The use, distribution or reproduction in other forums is permitted, provided the original author(s) or licensor are credited and that the original publication in this journal is cited, in accordance with accepted academic practice. No use, distribution or reproduction is permitted which does not comply with these terms. 